\title{
Should Oxygen Therapy Be Tightly Regulated to Minimize Hyperoxia in Critically Ill Patients?
}

\author{
Richard H Kallet MSc RRT FAARC Richard D Branson MSc RRT FAARC
}

\author{
Introduction \\ Pro Argument: Oxygen Therapy Should Be Tightly Regulated to Avoid \\ Hyperoxia \\ Historical Context \\ Evolution and Genetic Influences on the Response to Hyperoxia \\ Overview: Cellular Signaling in VILI and the Role of ROS \\ Impact of VILI and Hyperoxic Acute Lung Injury \\ Long-Term Impact of Supplemental Oxygen Therapy in Chronic Lung \\ Disease \\ Systemic Effects of Hyperoxia \\ Permissive Hypoxemia as a Strategy to Control Hyperoxia \\ Summary of the Pro Argument \\ The Argument Against Strict Control of $\mathbf{F}_{\mathbf{I O}_{2}}$ \\ Oxygen and Outcomes in Ventilated Patients \\ The Conservative Oxygen Therapy Trials \\ The Con Summary \\ Excessive $\mathrm{F}_{\mathrm{IO}_{2}}$ in Other Conditions \\ Myocardial Infarction/Cardiac Arrest \\ Traumatic Brain Injury \\ Stroke \\ Conclusions
}

\begin{abstract}
Oxygen is both lifesaving and toxic. Appropriate use of oxygen aims to provide a balance between the two effects. Although local oxygen toxicity to the lung is well accepted, recent evidence has called into question the negative consequences of hyperoxemia in other organ beds. Hyperoxia following cardiac arrest, traumatic brain injury, and stroke has been shown to worsen outcomes. The role of hyperoxemia in mechanically ventilated patients, in the face of non-toxic inspired oxygen concentrations, is less clear. This paper will review the data for and against the use of conservative oxygen targets and the avoidance of hyperoxemia in mechanically ventilated patients. Key words: hyperoxia; hyperoxic acute lung injury; lung protective ventilation; oxygen toxicity; reactive oxygen species; ventilator-induced lung injury. [Respir Care 2016;61(6):801-817. (c) 2016 Daedalus Enterprises]
\end{abstract}

\section{Introduction}

Several years ago during a RespiRAtory CARE Journal Conference on oxygen, ${ }^{1}$ Editor Emeritus Dr David Pierson quipped that "oxygen toxicity is like Bigfoot, everyone has heard of it, but nobody has actually seen it". The question of whether hyperoxia is a relevant clinical concern is prob- lematic for several reasons. These include the complexity of tissue injury and related inflammatory processes, the impact of therapeutic interventions, and inter-individual genetic variability. In addition, the issue is influenced by how the debate over hyperoxia has played out over the past 60 years. That historical context continues to color contemporary perceptions and attitudes regarding the clin- 
ical importance of hyperoxia. Even now, when interest in ventilator-induced lung injury (VILI) dominates the discussion of mechanical ventilation, the contributory role of hyperoxia is still considered to be of secondary importance. ${ }^{2}$ In this paper, we debate both sides of this issue. The pro argument incorporates background information necessary to appreciate the complexity of the topic.

\section{Pro Argument: Oxygen Therapy Should Be Tightly Regulated to Avoid Hyperoxia}

Pulmonary oxygen toxicity, now referred to as hyperoxic acute lung injury, has been consistently reproduced in numerous animal models since Antoine Lavoisier's experiments in $1783 .{ }^{1}$ In essence, exposure to $\mathrm{F}_{\mathrm{IO}_{2}} \geq 0.70$ for several days leads to progressive lung injury; the severity of symptoms and pulmonary lesions are dependent upon both the concentration and duration. Breathing an $\mathrm{F}_{\mathrm{IO}_{2}} \geq 0.80$ for approximately 3-6 d typically is fatal to most animals. However, there also appear to be pronounced interspecies and even subspecies differences in the inflammatory response to hyperoxia. Hyperoxic acute lung injury is almost uniformly fatal in smaller species (eg, mice, rats, guinea pigs, rabbits), whereas humans appear more resistant, tending to acclimate after a period of approximately 7-10 d through hyperplasia of alveolar type-II cells. ${ }^{1}$ Nonetheless, over 230 years of data strongly suggest that breathing hyperoxic gas mixtures is toxic to human lungs, and there looms the distinct possibility that hyperoxia may be fatal in patients possessing a genetic predisposition. ${ }^{3}$

\section{Historical Context}

Medical interest in hyperoxia resulted from the intersection of several events in the mid-20th century, namely military demands related to high-altitude aviation and scuba diving during World War II and the increasing availability of $\mathrm{O}_{2}$ therapy to treat cardiopulmonary diseases. Begin-

\footnotetext{
Mr Kallet is affiliated with Respiratory Care Services, University of California San Francisco Department of Anesthesia at San Francisco General Hospital, San Francisco, California. Mr Branson is affiliated with the Department of Surgery, University of Cincinnati, Cincinnati, Ohio.

Mr Kallet and Mr Branson presented a version of this paper at the 54th RespiRATORY CARE Journal Conference, "Respiratory Care Controversies III," held June 5-6, 2015, in St Petersburg, Florida.
}

Mr Branson has disclosed relationships with Mallickrodt, Medtronic, Meiji Pharmaceuticals, Bayer, and Ventec. Mr Kallet has no conflicts to disclose.

Correspondence: Richard H Kallet MSc RRT FAARC, Department of Anesthesia, University of California San Francisco at San Francisco General Hospital NH:GA-2, 1001 Potrero Avenue, San Francisco, CA 94110.

DOI: $10.4187 /$ respcare. 04933 ning in the 1950s, the first reports of hyperoxic acute lung injury in humans began to appear in the medical literature. ${ }^{4,5}$ However, it was only in the 1960s, with the establishment of the ICU and prolonged mechanical ventilation as well as hyperbaric $\mathrm{O}_{2}$ therapy, that serious concern over clinical $\mathrm{O}_{2}$ toxicity arose in response to numerous case reports in both adults and neonates. ${ }^{1}$

However, these early reports implicating hyperoxia grossly overstated the problem and virtually ignored over a century of animal research. The excessive attribution of the development or perpetuation of acute respiratory failure to hyperoxia was in part due to the pervasive lack of knowledge regarding ARDS and VILI as well as the limitations of $\mathrm{O}_{2}$ delivery in early mechanical ventilators. It was only with the publication of the seminal report describing ARDS $^{6}$ as well as other studies examining the pathophysiology of ARDS, ${ }^{7-9}$ the technical problems associated with respiratory care equipment, ${ }^{10-12}$ and the elucidation of VILI ${ }^{13-15}$ that the role of hyperoxia was placed into a more realistic perspective. Unfortunately, when misconceptions cloaking a particular phenomenon are dispelled, an overreaction tends to occur in the opposite direction, fostering an attitude of excessive skepticism. The current debate must be framed within this context. The overarching question in 2016 is how, to what extent, and in which context does hyperoxic acute lung injury (and, therefore, the need for tightly controlling $\mathrm{F}_{\mathrm{IO}_{2}}$ ) impact morbidity and mortality during critical illness.

\section{Evolution and Genetic Influences on the Response to Hyperoxia}

The influence of hyperoxia on patient outcomes, particularly in ARDS, is difficult to isolate because of the complex interplay of mechanisms that activate the same injury response pathways. Recent advances in our understanding of both inflammation and the role of genetics suggest that the problem presented by hyperoxia transcends the imbalance between reactive oxygen species (ROS) production and antioxidant defense mechanisms. Rather, hyperoxia acts as an external stressor that strongly influences genetic-environmental interactions. One sobering example is that exposure to hyperoxia during perinatal life profoundly impacts the development of several diseases later in life, believed to be mediated by subsequent alterations in genetic expression that follows exposure. ${ }^{16}$

Biological evolution has been intertwined with the rise of planetary $\mathrm{O}_{2}$ concentrations, which have fluctuated cyclically with extremes between $\sim 10$ and 35\%.17,18 This exerted evolutionary pressure for life forms to devise adaptive strategies for successfully maintaining aerobic metabolism. Implications for the current debate stem from the fact that the explosion in mammalian evolution began approximately 200 million years ago. During this period (Tri- 
assic-Jurassic), atmospheric $\mathrm{O}_{2}$ concentrations plummeted from approximately $35 \%$ to $10 \%$, so that selective pressures encoded in the genome favored animals with efficient respiratory systems. What characterized this period in eukaryote evolution was an enhanced ability to adjust metabolism through hypoxic-responsive gene expression. Another (preceding) evolutionary characteristic was segregating metabolic function (oxidation-reduction) away from cellular DNA to prevent oxidative stress and genetic damage. ${ }^{19}$

Thus, coping with hypoxia, rather than hyperoxia, favored natural selection. But this raises questions regarding the efficiency of co-evolving antioxidant defense mechanisms in mammals whose evolutionary journey began breathing an inspired $\mathrm{O}_{2}$ tension of approximately $70-100 \mathrm{~mm} \mathrm{Hg}$. Moreover, many ancestral species dwelled predominantly in subterranean habitats that probably enhanced their ability to adapt to hypoxic environments. ${ }^{20}$ It is very likely that these genetically coded strategies influence all current organisms' responses to hyperoxia in ways that we do not yet fully comprehend.

\section{Overview: Cellular Signaling in VILI and the Role of ROS}

In regard to VILI, the current thinking is that the innate immune system plays a crucial role in both the initiation and progression of lung inflammation irrespective of initiating events. ${ }^{21}$ Known as damage-associated molecular patterns, they represent front-line cellular defenses against both pathogens and mechanical and chemical stressors. These encompass a large family of intracellular molecules known as Toll-like receptors released in response to various stimuli, including cell death (necrosis, apoptosis), immune cell activation, and debris released from the breakdown of the basement membrane. ${ }^{21}$ Toll-like receptors, in turn, activate intracellular stores of nuclear factor kappa B, a crucial molecule that activates a variety of genes involved in cellular defense mechanisms. ${ }^{22}$

Thus, nuclear factor kappa B can be activated by numerous stimuli present during critical illness, including ROS, pro-inflammatory cytokines, endotoxins, viruses, and stretch-related lung injury. ${ }^{22,23}$ Interestingly, nuclear factor kappa B is suppressed by the presence of antioxidants. ${ }^{22} \mathrm{In}$ addition, nuclear factor kappa B stimulation by both stretchrelated injury and hyperoxia induces the release of plasminogen activator inhibitor-1 and tissue factor by the airway and alveolar epithelial cells, endothelial cells, macrophages, and fibroblasts. ${ }^{24,25}$ Stimulation of plasminogen activator inhibitor- 1 and tissue factor induces the coagulation cascade, resulting in alveolar and small airway fibrin deposition. Therefore, both VILI and hyperoxic acute lung injury perpetuate lung damage through a common mechanism and may act either synergistically or additively (Fig. 1). Crucial for the advancement of lung-protective ventilation strategies is to ascertain whether an optimal balance between supplemental $\mathrm{O}_{2}$ therapy and mechanical ventilation can be achieved to minimize the deleterious effects of both.

\section{Impact of VILI and Hyperoxic Acute Lung Injury}

Several additional animal models found that either pretreating the lungs with hyperoxia before high-stretch tidal volume $\left(\mathrm{V}_{\mathrm{T}}\right)$ or combining hyperoxia with highstretch ventilation significantly magnifies the degree of VILI. ${ }^{24,26-36}$ These models mimic common clinical strategies in managing ARDS and other forms of acute respiratory failure before the advent of lung-protective ventilation. In brief, compared with controls, high- $\mathrm{V}_{\mathrm{T}}$ ventilation with ambient $\mathrm{F}_{\mathrm{IO}_{2}}(0.21)$, or a physiologic $\mathrm{V}_{\mathrm{T}}$ with hyperoxia, the combination of high- $\mathrm{V}_{\mathrm{T}}(18-30 \mathrm{~mL} / \mathrm{kg})$ ventilation, and hyperoxia $\left(\mathrm{F}_{\mathrm{IO}_{2}}=0.8-1.0\right)$ markedly enhanced numerous signifiers for VILI, including: altered-permeability pulmonary edema formation, ${ }^{24,26,27,31,32}$ diffuse interstitial and alveolar hemorrhage, ${ }^{33,34}$ decreased surfactant production (Fig. 2), ${ }^{28}$ and lung compliance, ${ }^{28,32,33}$ increased inflammatory mediator expression (Fig. $3)^{24,26-28,31,36}$ as well as increased apoptosis, ${ }^{26,33,34}$ and increased alveolar infiltration by neutrophils. ${ }^{24,26,27,31-33,36}$ Similar results were found even when moderate hyperoxia $\left(\mathrm{F}_{\mathrm{IO}_{2}}=\right.$ 0.5) was combined with a $\mathrm{V}_{\mathrm{T}}$ of $25 \mathrm{~mL} / \mathrm{kg} .{ }^{29}$ Although several of the studies cited above examined the effects using either a neonatal ${ }^{31,32}$ or an adult animal model, $24,26-29$ the pathological findings have been similar.

Moreover, in subjects with ARDS managed with low- $\mathrm{V}_{\mathrm{T}}$ protective ventilation, prolonged (ie, median $17 \mathrm{~h}$, interquartile range $8-33 \mathrm{~h}$ ) unnecessary exposure to relatively higher $\mathrm{F}_{\mathrm{IO}_{2}}$ despite adequate oxygenation (ie, $\mathrm{F}_{\mathrm{IO}_{2}}>0.50$ with $\mathrm{S}_{\mathrm{pO}_{2}}>92 \%$ ) was associated with worsening oxygenation index at $48 \mathrm{~h}$ in a dose-response manner. ${ }^{38}$ Over $50 \%$ of the relatively hyperoxic cohort were managed with an $\mathrm{F}_{\mathrm{IO}_{2}}$ of $>0.70$, and $>70 \%$ of the study sample were managed for $41 \%$ of the first $48 \mathrm{~h}$ of ARDS with an excessive $\mathrm{F}_{\mathrm{IO}_{2}}(\sim 20 \mathrm{~h})$. The hyperoxic cohort had significantly longer duration of mechanical ventilation and ICU stay, although mortality was not different. Despite the obvious mathematical linkage between $\mathrm{F}_{\mathrm{IO}_{2}}$ and oxygenation index, these results suggest the possibility that prolonged exposure to hyperoxia may contribute to pulmonary dysfunction in the presence of acute lung inflammation.

Other factors also appear to influence VILI and hyperoxic acute lung injury. To some extent, injury appears to be mediated by whether adult or elderly animals are examined. Despite a $6-\mathrm{mL} / \mathrm{kg} \mathrm{V}_{\mathrm{T}}$, elderly rats exposed to a $\mathrm{F}_{\mathrm{IO}_{2}}$ of 1 for 3-6 h suffered greater deterioration in oxygenation and more acute hypercapnia than adult rats. ${ }^{35}$ These findings also corresponded with greater pulmonary capillary leak, pro-inflammatory cytokines, and increased ROS levels associated with cell membrane damage and 


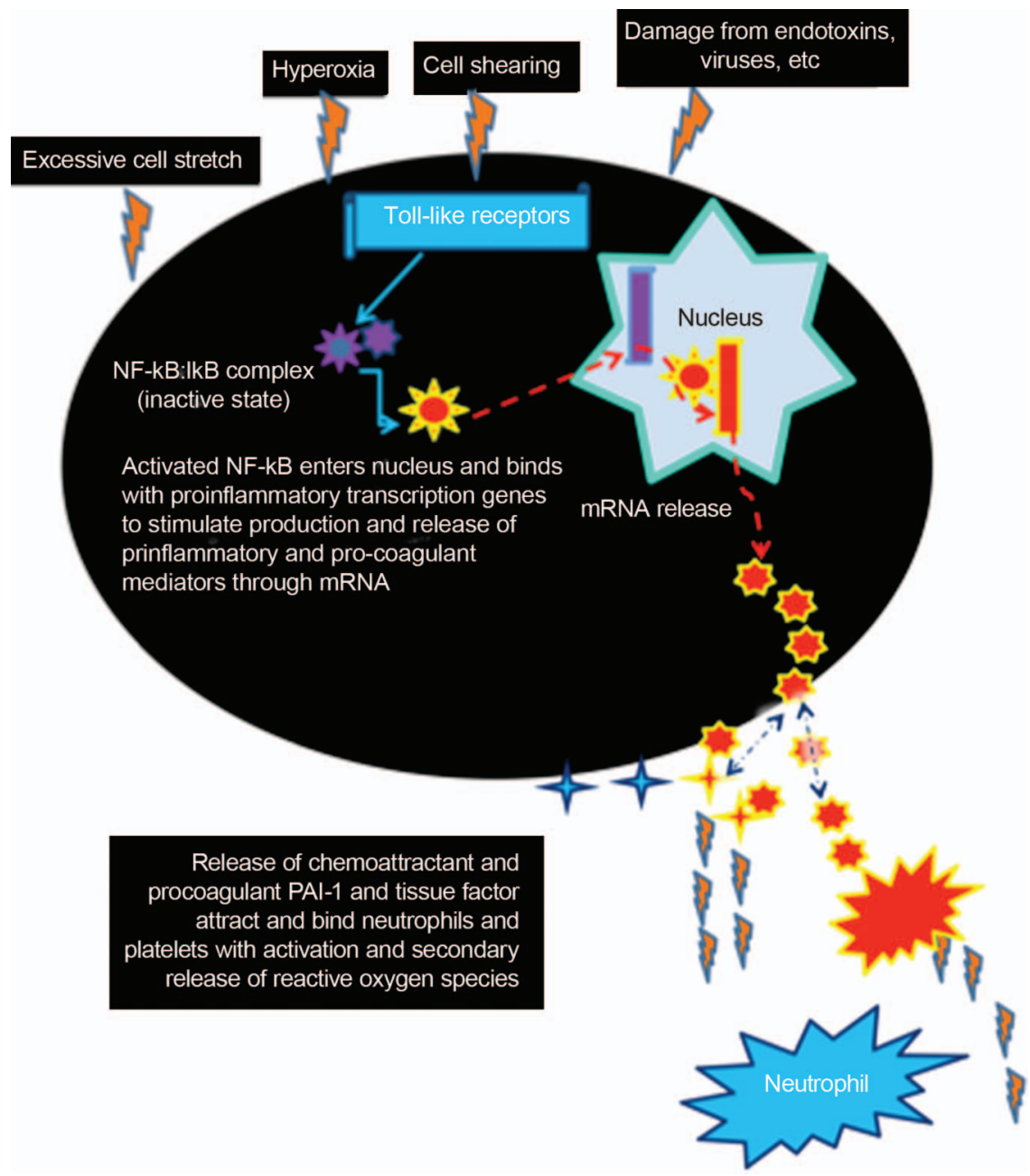

Fig. 1. Schematic representation of intracellular inflammatory pathway illustrating that both hyperoxia and mechanical lung injury from excessive stretch or shearing use the same intracellular pathways for initiating the inflammatory cascade. NF- $\kappa$ B $=$ nuclear transcription factor kappa B; PAl-1 = plasminogen activator inhibitor-1; mRNA = messenger ribonucleic acid. See text for a detailed description.

neutrophil activation. This may reflect the fact that over the life span, accumulative oxidative damage necessarily results in degeneration of DNA, proteins, and other macromolecules that either intensifies acute ROS damage or reflects the diminished antioxidant defense mechanisms of aging organisms due to genetic damage. It is estimated that the number of oxidative hits transiently damaging each cell's DNA is approximately $10,000 /$ cell/d for humans and 100,000/cell/d in rats. ${ }^{39}$ This reflects the fact that oxidative injury is intimately associated with the level of aerobic metabolism (which is 7 times higher in rats than in humans). ${ }^{39}$ It also explains the accelerated impact of VILI and hyperoxic acute lung injury in small mammals compared with humans and why generalizing the results of preclinical studies to humans must remain circumspect, at least regarding the rapidity and severity of oxidative injury.

Probably the most intriguing discovery was that alveolar epithelial cell cultures exposed to both $48 \mathrm{~h}$ of hyper- oxia (0.8-0.9) and excessive strain caused pathological remodeling and reorganization of the cytoskeleton. ${ }^{30} \mathrm{Hy}-$ peroxia stiffened the cell membrane and increased its resistance to deformation during simulated tidal stretch. As the cells were attached to an artificial basement membrane, the introduction of a tidal strain of $20 \%$ (5 times greater than estimated normal $\mathrm{V}_{\mathrm{T}}$ strain) resulted in substantial detachment of alveolar cells from their supporting matrix. The investigators speculated that to prevent injury, the deformation characteristics of the alveolar cells and the extracellular matrix (to which they are attached through linkage between the cytoskeleton and integrins) $)^{40}$ should approximate one another. The loss of alveolar epithelial cell membrane pliability (relative to the basement membrane) from oxidative stress appears to induce shearing that enhances stretch-induced injury.

The preclinical evidence, using several different species, clearly demonstrates that hyperoxia magnifies the 

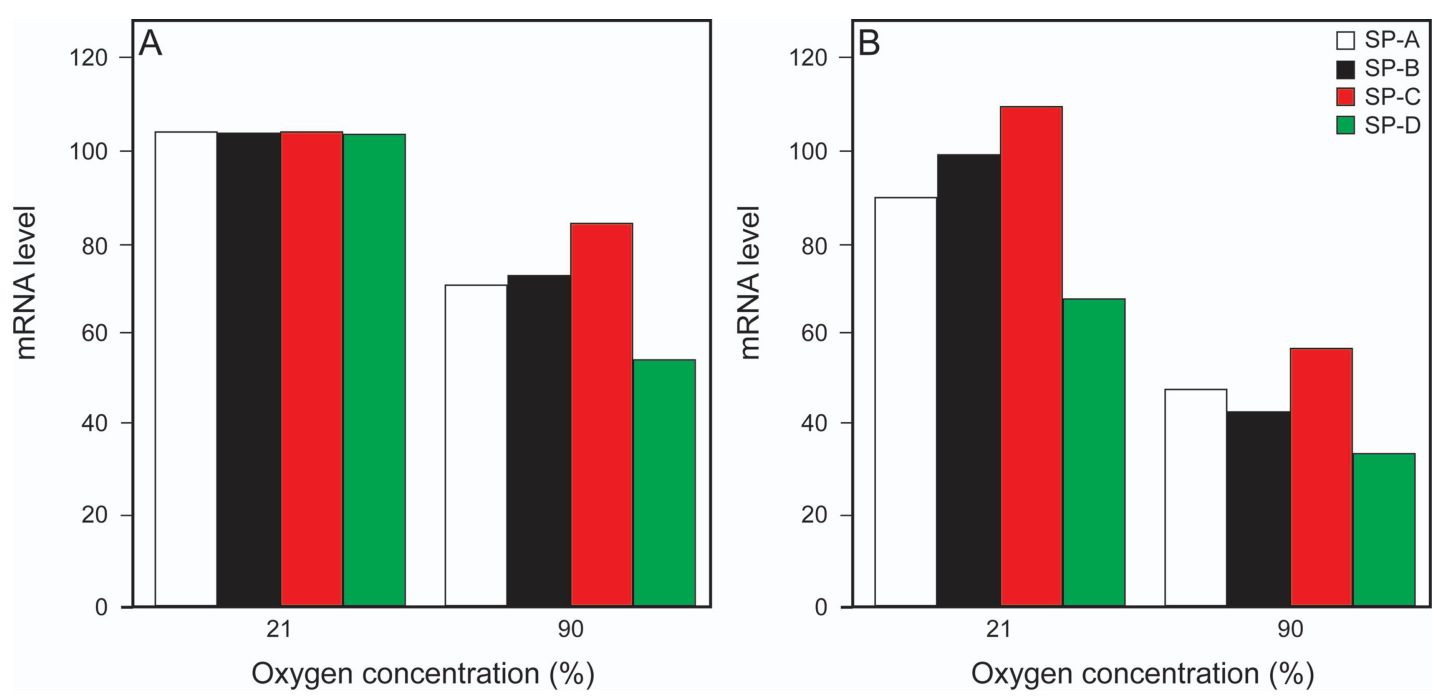

Fig. 2. The effects of high-stretch tidal ventilation with an oxygen concentration of either 21 or $90 \%$ on surfactant proteins (SP-A to SP-D) at the mRNA level (signifier for surfactant protein production). A: Non-stretched lungs. B: High-stretched lungs. Excessive stretch in a hyperoxic environment inhibited surfactant function in this experiment (including reduced lung compliance), in part illustrated by reduced mRNA levels for producing these proteins. Both SP-B and SP-C are associated with maintaining alveolar stability, whereas SP-A and SP-D are part of the innate immune system and protect against bacterial, fungal, and viral infection. ${ }^{37}$ This suggests that stretch-related injury in conjunction with hyperoxia enhances lung instability and susceptibility to pulmonary and systemic infection. Data are shown as mean values. Data from Reference 28.

effects of VILI induced by mechanical forces during mechanical ventilation. These models were done using an extraordinarily high $\mathrm{V}_{\mathrm{T}}$ in animals with normal lungs. In the experiments that used a physiologic $\mathrm{V}_{\mathrm{T}}(7 \mathrm{~mL} / \mathrm{kg})$ for comparison, the deleterious effects of hyperoxia generally were not seen within the brief study periods (typically 4-5 h). ${ }^{24,27}$ However, the history of VILI research is instructive in this regard. The significance of Webb and Tierney's $\mathrm{s}^{13}$ classic research on VILI was not appreciated initially, because their model was based on normal lungs ventilated with an extraordinarily large $\mathrm{V}_{\mathrm{T}}$ not used in clinical practice. The clinical relevance only became apparent once it was realized that lung injury in ARDS is heterogeneously distributed, so that commonly used $V_{T}$ levels of $12-15 \mathrm{~mL} / \mathrm{kg}$ were functionally equivalent to $40 \mathrm{~mL} / \mathrm{kg}$ in an adult whose normally aerated lung tissue approached that of a 5-y-old child. ${ }^{41}$

Thus, $\mathrm{V}_{\mathrm{T}}$ size is a relative factor in generating VILI based upon the amount and distribution of aerated tissue. Regional lung hyperinflation with hyperoxic gas probably potentiates tissue injury. This was exemplified by Terragni et al, ${ }^{42}$ who reported a subgroup of subjects with moderate ARDS, in whom a substantial portion of the $6-\mathrm{mL} / \mathrm{kg} \mathrm{V}_{\mathrm{T}}$ was preferentially distributed to overdistended regions. Despite producing what has long been considered to be a protective plateau pressure $\left(29 \mathrm{~cm} \mathrm{H}_{2} \mathrm{O}\right)$, these subjects had significantly higher pro-inflammatory mediator levels in their bronchoalveolar lavage fluid compared with those whose $\mathrm{V}_{\mathrm{T}}$ was distributed to normally aerated tissue (with a corresponding plateau pressure of $26 \mathrm{~cm} \mathrm{H}_{2} \mathrm{O}$ ). In fact, those whose ventilation was distributed to overdistended regions also were sicker and were ventilated at a toxic $\mathrm{F}_{\mathrm{IO}_{2}}$ (0.8 vs 0.56) ${ }^{42}$ Furthermore, it should be noted that radiologically normal lung areas in ARDS also show evidence of marked inflammatory activity. ${ }^{43}$ Therefore, the appearance of normal lung in ARDS is deceptive. These less or perhaps minimally damaged tissues remain susceptible to further damage from the combined effects of regional hyperinflation and oxidative damage.

\section{Long-Term Impact of Supplemental Oxygen Therapy in Chronic Lung Disease}

In the early 1970 s, Petty et al ${ }^{44}$ reported that almost half of their subjects with COPD on long-term $\mathrm{O}_{2}$ therapy ( $\sim 2 \mathrm{y}$ on an estimated $\mathrm{F}_{\mathrm{IO}_{2}}$ of $0.22-0.27$ ) had classic findings of $\mathrm{O}_{2}$ toxicity on autopsy exam (ie, capillary proliferation, interstitial fibrosis, epithelial and hyperplasia). Although this finding appeared to contradict the implications of preclinical research, mounting evidence now suggests a much more complex pathophysiologic process of oxidative injury in this patient population. COPD patients suffer from oxidative stress related to chronic inflammation both from prolonged exposure to cigarette smoke and infectious exacerbations. ${ }^{45}$ Subjects with COPD have been found to have a protein thiol deficiency that impairs antioxidant defenses, so that even short-term (18-48-h) supplemental $\mathrm{O}_{2}$ at $2 \mathrm{~L} / \mathrm{min}$ amplifies ROS production. ${ }^{46}$ However, as others have noted, oxidative stress in COPD is sustained 

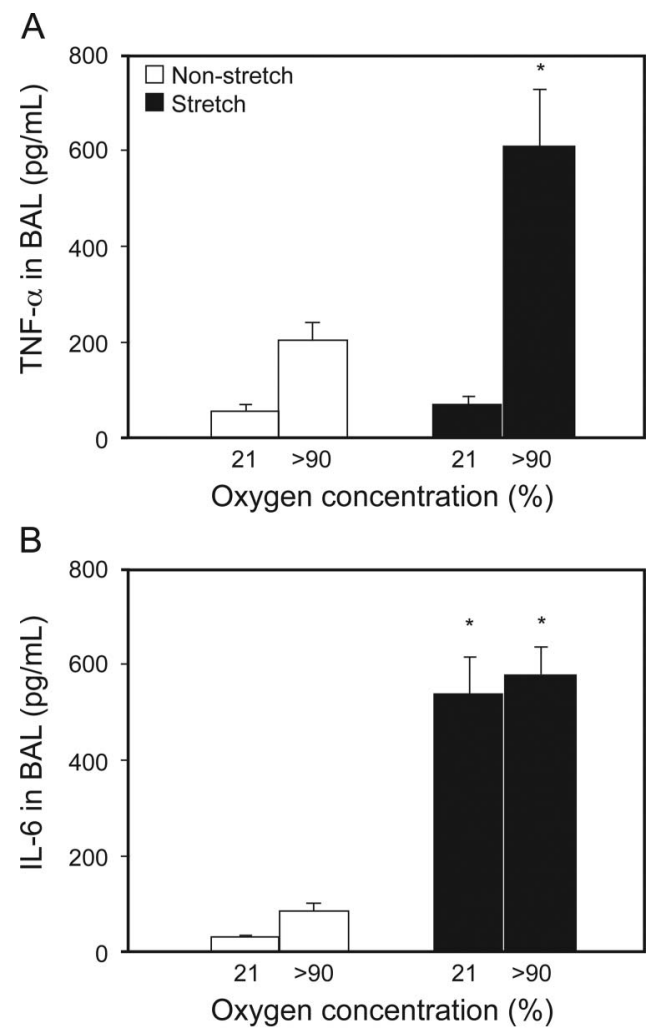

Fig. 3. Pro-inflammatory mediator concentrations from bronchoalveolar lavage (BAL) fluid taken from animals exposed to highstretch tidal ventilation with an oxygen concentration of either 21 or $90 \%$. Levels of tumor necrosis factor $\alpha$ (TNF- $\alpha$ ) were significantly higher under conditions of excessive stretch plus hyperoxia and appeared to have an interactive effect (A). On the other hand, interleukin-6 (IL-6) levels were significantly higher than in control conditions but did not appear to appear to enhance the inflammatory effect of each other (B). * $P<.05$ versus non-stretch group at $21 \%$ oxygen concentration. From Reference 28 , with permission.

long after patients cease smoking. ${ }^{45}$ This suggests that other factors, such as secondary carbonyl stress (the formation of highly reactive organic molecules secondary to long-term damage from oxidative stress), play a role in perpetuating lung injury. ${ }^{45}$ Moreover, environmental pollution also produces numerous respirable oxidants that enter the lungs and other tissues, generating ROS. Patients with COPD are particularly susceptible to this form of environmental oxidative injury. ${ }^{46-49}$ Thus, the contribution of $\mathrm{O}_{2}$ therapy cannot easily be parsed out from other contributing factors. Regardless, the benefits of supplemental $\mathrm{O}_{2}$ therapy to patients with severe chronic lung disease far outweigh the additional risks from oxidative damage.

\section{Systemic Effects of Hyperoxia}

It has been long recognized that despite the lungs being the first organ severely afflicted by hyperoxia, a wide range of damage occurs to distant organs that apparently is dependent upon local perfusion and metabolic rate..$^{50}$ At the basal metabolic rate, the organs with the highest $\mathrm{O}_{2}$ consumption and perfusion share are the heart, the muscles, the brain, and the abdominal viscera (Fig. 4).$^{51}$ It has been observed that hyperoxia "will produce progressive cellular damage and death in one organ system after another until the process is stopped by pulmonary damage or death of the animal." 50

The most salient concern regarding the systemic effects of hyperoxia is that $\mathrm{O}_{2}$ induces systemic vasoconstriction and decreases cardiac output, reducing perfusion to most tissue beds, including the brain, heart, skeletal muscle, and skin. ${ }^{52}$ Reduction in perfusion is linear and inversely proportional to the $\mathrm{P}_{\mathrm{aO}_{2}}$. Systemic perfusion appears to decrease when $\mathrm{P}_{\mathrm{aO}}$ exceeds $150 \mathrm{~mm} \mathrm{Hg}$, with a maximum decline reaching $20 \% .{ }^{52}$ This perhaps is why the proposed cutoff for clinically important arterial hyperoxia is considered by some to be a $\mathrm{P}_{\mathrm{aO}_{2}}$ of $>150 \mathrm{~mm} \mathrm{Hg.}{ }^{53}$

The most cogent explanation for hyperoxia-induced vasoconstriction is that the production of the ROS superoxide anion inactivates nitric oxide (NO) by: (1) reducing L-arginine (a precursor of NO); (2) by directly inhibiting the enzyme NO synthase, or (3) by its effect as a ligand that prevents unloading of $\mathrm{NO}$ from hemoglobin. ${ }^{52}$ Adding to the uncertainty is that the vasoconstrictor effects of hyperoxia may be temporal in nature, because hyperoxia also paradoxically increases L-arginine and NO synthase. Therefore, the deleterious effects of hyperoxia, particularly during reperfusion following ischemic injury, may need to take into account the nature and duration of ischemia or trauma.

Allowing hyperoxia in patients with various medical conditions has become an area of concern, although highlevel evidence generally is lacking. ${ }^{52-58}$ In brief, there is clear evidence in normal subjects that vasoconstriction in response to hyperoxia is dose-dependent, can be observed within a few minutes, and causes a mean reduction in local perfusion of $30 \% .{ }^{54}$ In retrospective studies of subjects post-cardiac arrest after the return of spontaneous circulation, sustained exposure to arterial hyperoxia has been associated with poorer neurological outcomes and increased risk of hospital mortality. ${ }^{53,56,57}$ Hyperoxia has also been used in the treatment of acute brain injury, wherein cerebral hypoxia causes secondary brain injury. ${ }^{55}$ Although some patients appear to benefit from hyperoxia, the results have been mixed, and the topic remains controversial. Of particular concern is the neurotoxic effect of ROS. Increased oxidative damage to brain tissue and higher mortality following 3-6 h of hyperoxia exposure has been demonstrated in animals with cerebral ischemia. ${ }^{55}$ In subjects with severe traumatic brain injury, hyperoxia had a paradoxical effect on regional brain perfusion of at-risk tissue $(<20 \mathrm{~mL} / 100 \mathrm{~g} / \mathrm{min})$ and also resulted in the least improvement in brain tissue $\mathrm{P}_{\mathrm{O}_{2}}$ compared with uninjured areas. ${ }^{59}$ 


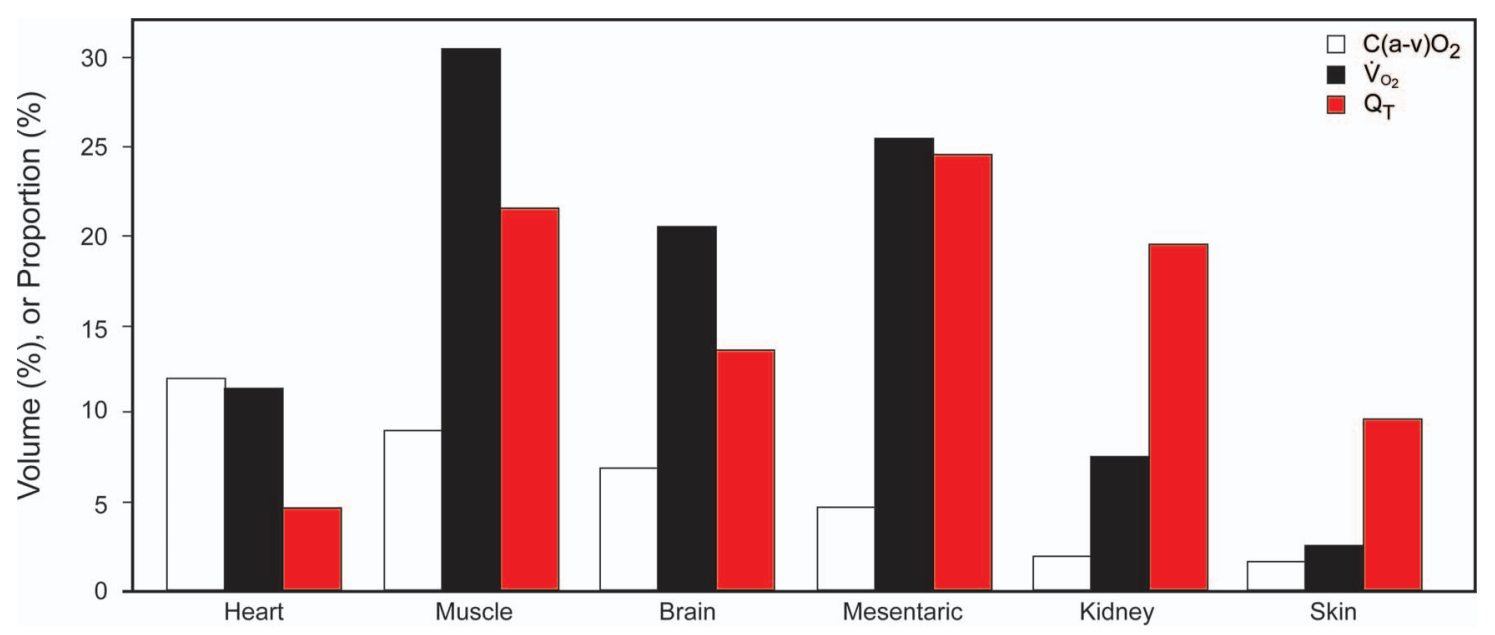

Fig. 4. Depiction of the highest oxygen-consuming and perfused organs in the body under resting conditions. The deleterious effects of hyperoxia on the viscera are markedly influenced by metabolic rate and perfusion. Although the kidneys, at first glance, appear to be at relatively low risk for oxygen toxicity based on oxygen consumption, this is deceptive, given the very high share of resting cardiac output. $\mathrm{C}(\mathrm{a}-\mathrm{v}) \mathrm{O}_{2}=$ arterial-venous oxygen content difference; $\dot{\mathrm{V}}_{\mathrm{O}_{2}}=$ percentage of the body's total volume of oxygen consumption; $\mathrm{Q}_{\mathrm{T}}=$ percentage of total body blood flow. Data from Reference 50 .

Ischemia-reperfusion injury exemplifies the $\mathrm{O}_{2}$ paradox, whereby re-establishing perfusion with oxygenated blood following an ischemic event paradoxically results in cellular contracture and necrosis. ${ }^{60}$ The mechanism causing both the initial and subsequent injury is the production of ROS. Thus, the predominant issue in many situations involving critically ill patients is the potential for hyperoxia to magnify damage resulting from ischemia-reperfusion injury.

In brief, ischemia triggers an oxidative burst by inducing nicotinamide adenine dinucleotide phosphate and xanthine oxidase release. This, in turn, reduces $\mathrm{O}_{2}$ into superoxide anion that damages cell membranes, thereby causing further ROS production. Thus, ischemic tissue becomes primed for sustaining further damage upon the reversal of ischemia. ${ }^{1,60,61}$ Tissue priming is at least partly caused by depletion of intracellular antioxidant defenses during the initial ischemic event. ${ }^{60}$ Upon reperfusion with oxygenated blood, ROS production is further stimulated, both by the presence of $\mathrm{O}_{2}$ and by the normal inflammatory cascade set in motion by tissue injury. ROS production is directly proportional to local tissue $\mathrm{P}_{\mathrm{O}_{2}}$, ${ }^{1}$ so that hyperoxia further augments ROS production and magnifies inflammation in the context of reduced antioxidant defenses. This has global consequences because the inflammatory cascade initiated by ischemia-reperfusion injury causes remote damage to other organ systems. ${ }^{61}$

Mounting clinical and preclinical evidence indicates that hyperoxia during cardiopulmonary bypass, ${ }^{58}$ following cardiac arrest, ${ }^{62}$ liver ischemia, ${ }^{63}$ and brain ischemia, ${ }^{64}$ provokes multi-organ damage, suggesting that hyperoxia should be avoided whenever possible. A meta-analysis of preclinical studies of cardiac arrest ${ }^{65}$ found that resuscita- tion with an $\mathrm{F}_{\mathrm{IO}_{2}}$ of 1 sustained for 60 min after the return of spontaneous circulation produced significantly greater neuronal damage and worse neurologic deficits compared with an $\mathrm{F}_{\mathrm{IO}_{2}}$ of 0.21 or titrated to maintain normal arterial oxygenation. Generalizing results from preclinical trials to clinical practice is highly problematic; therefore, the implications for altering $\mathrm{O}_{2}$ administration during resuscitation cannot be recommended at this time. However, the avoidance of hyperoxia during the post-arrest period in order to reduce harm associated with ischemia-reperfusion injury is feasible. Hyperoxia detected in the ICU following cardiopulmonary resuscitation carries a higher risk of death compared with normoxia (odds ratio 1.8 [95\% CI 1.5-2.2], $P<.01) .{ }^{66}$ In fact, mortality was significantly higher in subjects with hyperoxia versus those with hypoxemia (proportional difference of $6 \%, P<.01$ ).

A similar risk for increased hospital mortality from exposure to hyperoxia $\left(\mathrm{P}_{\mathrm{aO}_{2}} \geq 300 \mathrm{~mm} \mathrm{Hg}\right)$ following acute brain injury from ischemic stroke also has been reported. ${ }^{67}$ Hospital mortality was $60 \%$ in the hyperoxic group compared with $53 \%$ in those exposed to hypoxemia $\left(\mathrm{P}_{\mathrm{aO}_{2}}\right.$ $<60 \mathrm{~mm} \mathrm{Hg}$ ) and $47 \%$ in those classified as being normoxic. After adjustment for other confounding variables, the odds ratio for death was significantly higher in the hyperoxia group compared with normoxia (odds ratio 1.7 [95\% CI 1.3-2.1], $P<.001)$ and also those exposed to hypoxemia (odds ratio 1.3 [95\% CI 1.1-1.7], $P<.01$ ). Likewise, using the same classification schema, exposure to hyperoxia following traumatic brain injury has also been independently associated with higher hospital mortality compared with normoxia (adjusted odds ratio 1.5 [95\% CI 1.02-2.4], $P<.04$ ) (Fig. 5). ${ }^{68}$ 


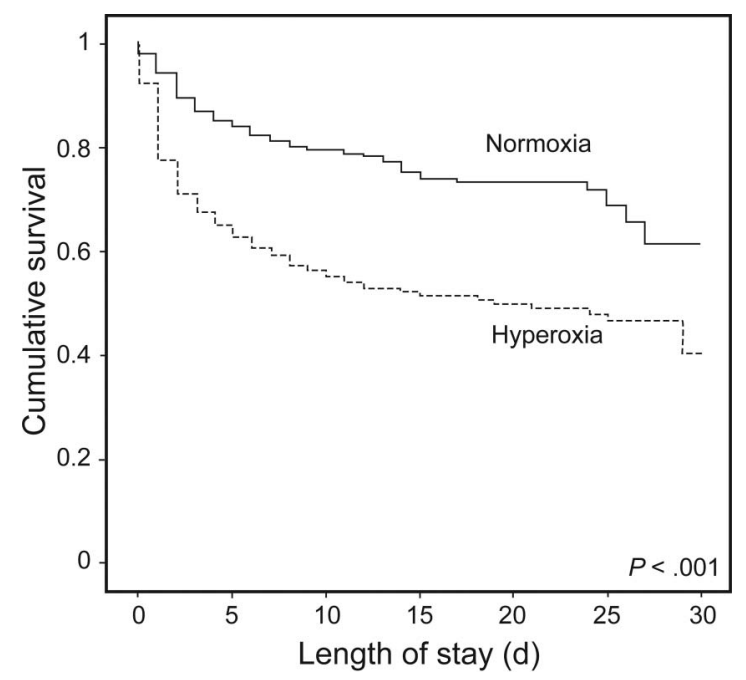

Fig. 5. Kaplan-Meier survival curve illustrating reduced survival in subjects with traumatic brain injury exposed to arterial hyperoxia. Similar Kaplan-Meier curves have been demonstrated when patients suffering ischemic stroke and post-cardiac arrest also were exposed to arterial hyperoxia. From Reference 63, with permission.

Furthermore, allowing hyperoxia during the prehospital and emergency department care of patients with acute COPD exacerbation is associated with a higher incidence of respiratory acidosis and need for mechanical ventilation as well as increased hospital mortality. ${ }^{69,70}$ In these studies, the intervention group had $\mathrm{O}_{2}$ therapy titrated to achieve an $\mathrm{S}_{\mathrm{pO}_{2}}$ of $88-92 \%$. The association with mortality does not appear to be related to hyperoxia per se but rather the secondary effects of hypercapnia and respiratory acidosis. Hypercapnia is independently associated with mortality in patients with COPD, ${ }^{71}$ yet it is unclear whether the association found in epidemiologic studies is merely a signifier of more severe disease. Regardless, the evidence demonstrating an association between hyperoxia-induced respiratory acidosis in the prehospital and emergency department setting with hospital mortality suggests a more acute process. For example, acute respiratory acidosis in COPD patients with pulmonary hypertension may worsen or induce cor pulmonale.

Finally, in a study involving $>36,000$ mechanically ventilated subjects from 50 ICUs in the Netherlands, both $\mathrm{P}_{\mathrm{aO}_{2}}$ and $\mathrm{F}_{\mathrm{IO}_{2}}$ in the first $24 \mathrm{~h}$ of mechanical ventilation have been associated with increased mortality. ${ }^{72}$ When analyzed as a continuous variable, initially increasing $\mathrm{P}_{\mathrm{aO}}$ was associated with decreased hospital mortality, as would be expected with reversal of severe hypoxemia, but then a secondary mortality increase appeared to occur once $\mathrm{P}_{\mathrm{aO}_{2}}$ began to increase beyond $150 \mathrm{~mm} \mathrm{Hg}$. In a multivariate regression model adjusting for other comorbidities, the association between mortality, $\mathrm{P}_{\mathrm{aO}}$, and $\mathrm{F}_{\mathrm{IO}_{2}}$ remained. These results suggest (but do not prove) that both pulmo- nary and systemic hyperoxia may negatively impact mortality through the mechanisms described earlier in this paper. Furthermore, the results underscore the importance of clinical management strategies that prevent hypoxemia while minimizing the incidence of hyperoxia.

\section{Permissive Hypoxemia as a Strategy to Control Hyperoxia}

Mounting evidence suggests that exposing patients to hyperoxia is harmful, in ways that are not obvious during routine clinical practice. This has led to the proposal that management should allow for permissive hypoxemia. This strategy is prefaced by adhering to strict parameters for hemoglobin concentration $(9-10 \mathrm{~g} / \mathrm{dL})$ and pharmacologically induced supranormal cardiac index $\left(>4.5 \mathrm{~L} / \mathrm{min} / \mathrm{m}^{2}\right)$ to maintain normal tissue $\mathrm{O}_{2}$ delivery. With these caveats in place, permissive hypoxemia allows patients to be managed with a $\mathrm{P}_{\mathrm{aO}_{2}}$ of $50-60 \mathrm{~mm} \mathrm{Hg} .{ }^{73}$ Although there exist isolated reports of patients with ARDS accompanied by very severe hypoxemia (ie, $\mathrm{P}_{\mathrm{aO}_{2}}<30 \mathrm{~mm} \mathrm{Hg}$ ) without evidence of tissue hypoxia, ${ }^{74}$ the margin for error is extremely narrow in patients susceptible to unanticipated bouts of acute desaturation or hemodynamic instability. Moreover, in the context of pharmacologically increasing cardiac work load, it is important to emphasize data establishing the deleterious effects of hypoxemia on right heart function in ARDS and its association with increased mortality. ${ }^{75,76}$

A sobering lesson came from early testing of permissive hypoxemia in the management of preterm infants during the BOOST II and SUPPORT trials. ${ }^{77,78}$ In these trials of $\mathrm{O}_{2}$ therapy, the intervention groups were titrated to maintain $\mathrm{S}_{\mathrm{pO}_{2}}$ between 85 and $89 \%$ versus between 91 and 95\%. In the SUPPORT trial, premature infants (24-27 weeks gestation) randomized to the lower $\mathrm{S}_{\mathrm{pO}_{2}}$ management arm had a significantly higher mortality rate $19.9 \%$ versus $16.2 \%, P=.04) .{ }^{77}$ Mortality was similarly higher in the lower $\mathrm{S}_{\mathrm{pO}_{2}}$ cohort of the BOOST II trial (23.1\% vs $15.9 \%$, $P=.002) .{ }^{78}$ As others have noted, ${ }^{79}$ there do not exist unambiguously acceptable, lower thresholds for tissue oxygenation that can be tolerated. Future technologies and biomarkers may make the permissive hypoxemia possible. But for now there appears to be no sound justification for introducing this strategy into clinical practice.

Irrespective of legitimate concerns with this approach, the concept of permissive hypoxemia is instructive, in that it serves as a reminder that most patients can be managed with a $\mathrm{P}_{\mathrm{aO}_{2}}$ between 60 and $80 \mathrm{~mm} \mathrm{Hg}$. This raises an issue regarding two potential bad habits in clinical practice. The first is allowing patients to be managed with sustained $\mathrm{S}_{\mathrm{pO}_{2}}$ of $98-100 \%$ without verifying the corresponding $\mathrm{P}_{\mathrm{aO}}$. The affinity of hemoglobin for $\mathrm{O}_{2}$ decreases as $\mathrm{P}_{\mathrm{aO}_{2}}$ exceeds $95 \mathrm{~mm} \mathrm{Hg}$, such that $\mathrm{P}_{a O_{2}}$ saturation normally reaches 
$100 \%$ when $\mathrm{P}_{\mathrm{aO}}$ is approximately $250 \mathrm{~mm} \mathrm{Hg} .{ }^{80}$ Decreasing affinity for $\mathrm{O}_{2}$ as hemoglobin approaches complete saturation, along with the inherent limitations of pulse oximetry in detecting arterial hyperoxia, means that when $\mathrm{S}_{\mathrm{pO}_{2}}$ is $>95 \%$, small increases in oxygenation detected by $\mathrm{S}_{\mathrm{PO}_{2}}$ may occur with very large changes in $\mathrm{P}_{\mathrm{aO}_{2}}{ }^{81}$

The second potential bad habit is maintaining a supernormal $\mathrm{P}_{\mathrm{aO}_{2}}$ (particularly on toxic levels of $\mathrm{F}_{\mathrm{IO}_{2}}$ ) to provide a buffer or margin of safety in case of acute desaturation. The $\mathrm{O}_{2}$-carrying capacity of plasma is minuscule $\left(0.003 \mathrm{~mL} / \mathrm{dL} / \mathrm{mm} \mathrm{Hg}\right.$ of $\left.\mathrm{P}_{\mathrm{aO}}\right)$ compared with hemoglobin $(1.39 \mathrm{~mL} / \mathrm{g} / \mathrm{dL}){ }^{82}$ Clinicians might be lulled into a false sense of security by maintaining a supernormal $\mathrm{P}_{\mathrm{aO}_{2}}$ in patients with tenuous oxygenation status. However, it offers a rather paltry $\mathrm{O}_{2}$ delivery buffer that would have a negligible impact in the face of increasing venous admixture. Therefore, the overall risk of maintaining some degree of arterial hyperoxia as a hedge against $\mathrm{P}_{\mathrm{aO}_{2}}$ desaturation probably outweighs the small potential benefit. For example, increasing the $\mathrm{P}_{\mathrm{aO}_{2}}$ from 100 to $150 \mathrm{~mm} \mathrm{Hg}$ (the cusp of significant arterial hyperoxia) increases $\mathrm{O}_{2}$ delivery capacity of the circulating blood volume (eg, $5 \mathrm{~L}$ ) by an estimated $15 \mathrm{~mL}$, or $<2 \%$ (assuming a normal oxyhemoglobin curve with a corresponding increase in $\mathrm{S}_{\mathrm{aO}_{2}}$ from 97 to $98 \%$ ). The idea that needing toxic levels of $\mathrm{F}_{\mathrm{IO}_{2}}$

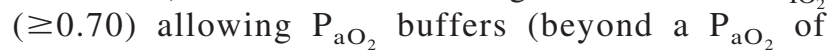
$100 \mathrm{~mm} \mathrm{Hg}$ ) are pointless based on current evidence because the potential harm outweighs any perceived peace of mind it may give to clinicians.

Similarly, maintaining arterial hyperoxia in patients suffering from shock during the peri-resuscitation period may paradoxically cause more harm than benefit by amplifying ischemic reperfusion injury. That being said, obviously transient hyperoxia during resuscitation is indicated (because the risks from hypoxia outweigh the potential risks from hyperoxia given our current level of knowledge) as is the use of transient hyperoxia during procedures such as intubation, wherein maintaining a pulmonary $\mathrm{O}_{2}$ reserve is prudent for ensuring patient safety in the case of mishap or difficulties during apneic periods.

\section{Summary of the Pro Argument}

In summary, humans evolved from an evolutional line that has extremely honed abilities to adapt to hypoxia but, like all other mammals, is not particularly endowed with robust antioxidant defense mechanisms at a cellular level to counter severe oxidative stress. Hyperoxic acute lung injury resulting from prolonged exposure to toxic levels of oxygen $\left(\mathrm{F}_{\mathrm{IO}_{2}} \geq 0.70\right)$ is a very valid concern in managing patients with acute respiratory failure because it probably exacerbates the underlying inflammatory process, necessitating mechanical ventilation as well as VILI. But there is also emerging evidence suggesting that internal organs (protected from atmospheric $\mathrm{O}_{2}$ concentrations) are probably more vulnerable to lower levels of hyperoxia than the lungs, the vulnerability magnified by both its metabolic rate and perfusion. In 2016, it is prudent to err on the side of caution by adopting both ventilator and ancillary therapy strategies that protect against hyperoxic acute lung injury and VILI. Part of these strategies involves avoiding $\mathrm{P}_{\mathrm{aO}_{2}}$ of $>100 \mathrm{~mm} \mathrm{Hg}$ whenever possible. Adopting the National Institutes of Health's ARDS Net ${ }^{37}$ parameters for $\mathrm{P}_{\mathrm{aO}_{2}}(55-80 \mathrm{~mm} \mathrm{Hg})$ and $\mathrm{S}_{\mathrm{pO}_{2}}(88-95 \%)$ appears particularly attractive in this regard because this provides a reasonable range for adequate oxygenation and may help clinicians to avoid or reduce the risks associated with both pulmonary and systemic hyperoxia.

\section{The Argument Against Strict Control of $\mathrm{F}_{\mathrm{IO}_{2}}$}

There is little doubt that oxygen is a potent drug and is one of the most commonly delivered medications in emergency and critical care. This is complicated by the fact that oxygen is often delivered without a prescription, at an unknown dose, and without predefined end points. ${ }^{83-85} \mathrm{Ox}$ ygen can be lifesaving, yet oxygen is also known to be toxic. Oxygen is a biologically active molecule that plays a part in host defense and the regulation of intracellular signaling pathways as well as in oxidative stress. ${ }^{86}$ Oxygen is both pro-inflammatory and anti-inflammatory. The duality of this life-giving diatomic molecule is ironic but tells the story of the complex nature of oxygen in human physiology (Table 1). As described in the pro argument, the toxicity of oxygen in animal models is well known, and further discussion on that point is unwarranted. ${ }^{16-35}$ The argument here is: Should we use conservative oxygen therapy and avoid hyperoxemia in mechanically ventilated patients?

The risk of excess oxygen should not be ignored, but neither should it be overstated. It is important to note that hyperoxia never occurs in nature. The electrochemistry that allowed the discovery of oxygen made possible medical advancements and unleashed the toxicity of oxygen. As noted by Severinghaus and Astrup, ${ }^{87}$ if oxygen were introduced as a drug today, it is unlikely that the FDA would ever approve its use.

\section{Oxygen and Outcomes in Ventilated Patients}

Over the last decade, 8 clinical trials have attempted to evaluate the impact of oxygen targets and hyperoxemia on outcome in mechanically ventilated subjects ${ }^{38,71,88-93}$ along with 2 meta-analyses. ${ }^{94,95}$ Of these, 4 have evaluated the use of so-called "conservative oxygen therapy." $89,91-93$ These will be considered in detail here in an effort to demonstrate what opinions the evidence supports. Some salient characteristics of each trial are shown in Table 2. 
Table 1. The Duality of the Hyperoxia in Critical Illness

\begin{tabular}{|c|c|c|c|}
\hline \multicolumn{4}{|c|}{ Hyperoxia: $\mathrm{F}_{\mathrm{IO}_{2}}=1.0$} \\
\hline \multicolumn{2}{|c|}{ Positive } & \multicolumn{2}{|r|}{ Negative } \\
\hline Effect & Result & Effect & Result \\
\hline $\begin{array}{l}\text { Decreased mitochondrial } \mathrm{O}_{2} \\
\text { consumption with increased } \\
\text { carbon dioxide oxidation }\end{array}$ & $\begin{array}{l}\text { Improved mitochondrial respiration } \\
\text { efficiency }\end{array}$ & $\begin{array}{l}\text { Decreased mitochondrial } \mathrm{O}_{2} \\
\text { consumption }\end{array}$ & Reduced ATP synthesis \\
\hline Increased oxyhemoglobin saturation & Increased $\mathrm{O}_{2}$ delivery & Reduced nitric oxide & Decreased microvascular perfusion \\
\hline Reduced nitric oxide & $\begin{array}{l}\text { Increased vascular resistance and } \\
\text { blood pressure }\end{array}$ & $\begin{array}{l}\text { Inhibited hypoxic pulmonary } \\
\text { vasoconstriction }\end{array}$ & $\begin{array}{l}\text { Absorption atelectasis, shunt and } \\
\text { impaired gas exchange }\end{array}$ \\
\hline Decreased inflammation & Reduced hypoxic inducible factor $\alpha$ & Increased ROS & Uncoupling of mitochondrial respiration \\
\hline Increased reactive oxygen species & Stimulation of host defenses & Increased inflammation & Nuclear factor kappa B \\
\hline $\begin{array}{l}\text { Improved microvascular } \mathrm{O}_{2} \\
\text { pressure }\end{array}$ & Enhanced $\mathrm{O}_{2}$ diffusion & Increased ROS & $\begin{array}{l}\text { Fall in nitric oxide and increased } \\
\text { oxidative stress }\end{array}$ \\
\hline $\begin{array}{l}\text { ROS }=\text { reactive oxygen species } \\
\text { ATP }=\text { adenosine triphosphate }\end{array}$ & & & \\
\hline
\end{tabular}

Table 2. Studies Evaluating the Impact of Hyperoxia on Outcomes in Mechanically Ventilated Subjects

\begin{tabular}{|c|c|c|c|c|c|}
\hline First Author & Study Method & Country & Sample Size & Effect/No Effect & Conclusions \\
\hline Eastwood $^{88}$ & Cohort & $\begin{array}{l}\text { Australia and } \\
\text { New Zealand }\end{array}$ & 152,680 & No effect & $\begin{array}{l}\text { In the first } 24 \mathrm{~h} \text {, only hypoxia was associated with in-hospital } \\
\text { mortality. Hyperoxia had no impact. }\end{array}$ \\
\hline de Jonge ${ }^{71}$ & Cohort & Netherlands & 36,307 & Effect & $\begin{array}{l}\text { In the first } 24 \mathrm{~h} \text {, high } \mathrm{F}_{\mathrm{IO}_{2}} \text { and both hypoxia and hyperoxia } \\
\text { were associated with in-hospital mortality. }\end{array}$ \\
\hline Suzuki $^{89}$ & $\begin{array}{l}\text { Before and after } \\
\text { intervention }\end{array}$ & Australia & 105 & No effect & $\begin{array}{l}\text { Conservative oxygen therapy was not associated with negative } \\
\text { clinical outcomes, whereas oxygen exposure was markedly } \\
\text { reduced. }\end{array}$ \\
\hline Aboab $^{90}$ & Experimental & France & 14 & No effect & $\begin{array}{l}\text { High } \mathrm{F}_{\mathrm{IO}_{2}} \text { in ARDS was associated with absorption atelectasis, } \\
\text { which could be reversed by PEEP. }\end{array}$ \\
\hline Rachmale $^{38}$ & Cohort & United States & 210 & Effect & $\begin{array}{l}\text { Both exposure to higher } \mathrm{F}_{\mathrm{IO}_{2}} \text { and longer duration of exposure } \\
\text { were associated with worsening oxygenation index at } 48 \mathrm{~h} \text {, } \\
\text { more days on mechanical ventilation, longer ICU stay, and } \\
\text { longer hospital stay. No mortality difference was noted. }\end{array}$ \\
\hline Suzuki $^{91}$ & Before and after & $\begin{array}{l}\text { Australia and } \\
\text { New Zealand }\end{array}$ & 105 & Effect & $\begin{array}{l}\text { Might be associated with decreased radiological evidence of } \\
\text { atelectasis, earlier weaning from mandatory ventilation } \\
\text { modes, and earlier first trial of spontaneous ventilation. }\end{array}$ \\
\hline Panwar ${ }^{92}$ & Interventional & Australia & 103 & No effect & $\begin{array}{l}\text { Supports the feasibility of a conservative oxygenation strategy } \\
\text { in ventilated patients. }\end{array}$ \\
\hline Helmerhorst $\mathrm{t}^{93}$ & Interventional & Netherlands & 15,045 & No effect & $\begin{array}{l}\text { Stepwise implementation of conservative oxygenation targets } \\
\text { was feasible, effective, and seemed safe in critically ill } \\
\text { subjects. }\end{array}$ \\
\hline
\end{tabular}

The practice of oxygen therapy during mechanical ventilation, when left to clinicians, is based on the long held belief that an $\mathrm{F}_{\mathrm{IO}_{2}}$ of $<0.60$ is non-toxic. In fact, early application of PEEP was frequently guided with the attempt to reduce $\mathrm{F}_{\mathrm{IO}_{2}}$ to non-toxic levels. Oxygen therapy is also commonly provided, such that $\mathrm{S}_{\mathrm{pO}_{2}}$ is sufficient to provide a cushion in the case of respiratory deterioration to prevent hypoxemia. By maintaining $\mathrm{P}_{\mathrm{aO}_{2}}$ on the upper flat part of the oxyhemoglobin disassociation curve, patients can tolerate sudden changes in lung function without hypoxemia. In many instances, this results in patients with $\mathrm{S}_{\mathrm{pO}_{2}}$ of $>96 \%$. However, this practice may also be seen as masking significant deterioration without monitors warning of harm. Additionally, the liquid oxygen source at a hospital is sufficient such that conserving oxygen is not a concern.

Hyperoxemia and clinician response was shown nicely in a Dutch trial ${ }^{96}$ that evaluated the impact of $\mathrm{F}_{\mathrm{IO}_{2}}$ settings and the resulting $\mathrm{S}_{\mathrm{pO}_{2}}$. These investigators found that when $\mathrm{F}_{\mathrm{IO}_{2}}$ was $>0.60$ and hyperoxia $\left(\mathrm{P}_{\mathrm{aO}_{2}}>120 \mathrm{~mm} \mathrm{Hg}\right)$ was present, the clinician response was to reduce $\mathrm{F}_{\mathrm{IO}_{2}}$ in approximately $80 \%$ of cases. However, when hyperoxemia was seen when $\mathrm{F}_{\mathrm{IO}_{2}}$ was $\leq 0.40, \mathrm{~F}_{\mathrm{IO}_{2}}$ was decreased in only a quarter of cases. This study of $>5,000$ subjects and 
$>120,000$ blood gas samples appears to represent the common approach to $\mathrm{F}_{\mathrm{IO}_{2}}$ around the world. This paper also provided the impetus for the studies of the impact of hyperoxemia that followed.

In an early physiologic study of high $\mathrm{F}_{\mathrm{IO}}$, Aboab et al ${ }^{90}$ compared an $\mathrm{F}_{\mathrm{IO}_{2}}$ of 0.6 and 1.0 at PEEP of 5 or $14 \mathrm{~cm} \mathrm{H}_{2} \mathrm{O}$ in an effort to determine the impact of high $\mathrm{F}_{\mathrm{IO}_{2}}$ on absorption atelectasis. In 14 consecutive subjects with a $\mathrm{P}_{\mathrm{aO}_{2}} / \mathrm{F}_{\mathrm{IO}_{2}}<300$, they found that breathing gas at an $\mathrm{F}_{\mathrm{IO}_{2}}$ of 1.0 was associated with de-recruitment as a result of absorption atelectasis. Although this is an elegant study, the outcome is not surprising and in fact does not inform us of useful information regarding the question at hand.${ }^{97}$ Clearly, hyperoxic lung conditions create well-known pulmonary dysfunction, but this does not address hyperoxemia.

In a follow-up study, the same Dutch investigators evaluated the impact of hyperoxemia on mortality in a retrospective, observational study of 5 ICUs. ${ }^{71}$ In a cohort of $>3,000$ subjects, they found a U-shaped relationship between $\mathrm{P}_{\mathrm{aO}_{2}}$ in the first $24 \mathrm{~h}$ and mortality. Specifically, the subjects with the lowest and highest $\mathrm{P}_{\mathrm{aO}_{2}}$ had the greatest mortality, whereas there was a linear relationship between $\mathrm{F}_{\mathrm{IO}_{2}}$ and death. They also confirmed previous findings that subjects in these ICUs tended to have $\mathrm{P}_{\mathrm{aO}}$ higher than values recommended in the literature. To be clear, this trial demonstrates that high $\mathrm{F}_{\mathrm{IO}_{2}}$ and both low and high $\mathrm{P}_{\mathrm{aO}_{2}}$ in the first $24 \mathrm{~h}$ are associated with in-hospital mortality. This trial in no way proves causation. The results can just as easily be explained by the severity of illness. Patients with hypoxemia who are refractory to treatment with oxygen may, in fact, have such severe pathology that death is expected. Similarly, high $\mathrm{F}_{\mathrm{IO}_{2}}$ is a marker for the severity of lung injury, cardiac function, and required support, again simply a surrogate for the degree of dysfunction.

A study from the Australian and New Zealand Intensive Care Society Clinical Trials Network (ANZICS) retrospectively evaluated the worst alveolar to arterial gradient during the first $24 \mathrm{~h}$ of ICU admission from 150 ICUs over a 9-y period. Using multivariate analysis, they attempted to determine the impact of $\mathrm{P}_{\mathrm{aO}_{2}}$ on mortality. ${ }^{88}$ After adjusting for site and physiologic variables, they identified a relationship between hypoxemia and outcome but not hyperoxemia and outcome. They concluded that in mechanically ventilated ICU subjects, the role of hyperoxemia in outcomes was at best uncertain.

A study from the Mayo Clinic was the first study to hint at a possible burden of hyperoxia and oxygen exposure on in-hospital lung function. ${ }^{38}$ This group evaluated $\mathrm{F}_{\mathrm{IO}_{2}}$ and the corresponding $\mathrm{P}_{\mathrm{aO}}$ in 210 subjects during the first $48 \mathrm{~h}$ of ventilatory support. They defined excessive $\mathrm{F}_{\mathrm{IO}_{2}}$ as $>0.5$, whereas $\mathrm{S}_{\mathrm{pO}_{2}}$ was $>92 \%$ (Fig. 6). The burden of excessive $\mathrm{F}_{\mathrm{IO}_{2}}$ was associated with a worsening of oxygenation index at $48 \mathrm{~h}$ in a dose-dependent fashion (Fig. 7). In those subjects with the greatest $\mathrm{F}_{\mathrm{IO}_{2}}$ burden, there was an asso-

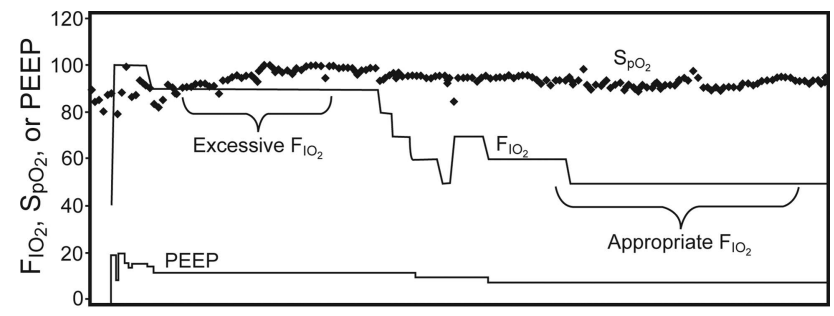

Fig. 6. Calculation of the excessive $\mathrm{F}_{\mathrm{IO}_{2}}$ burden in a singe patient. From Reference 37.
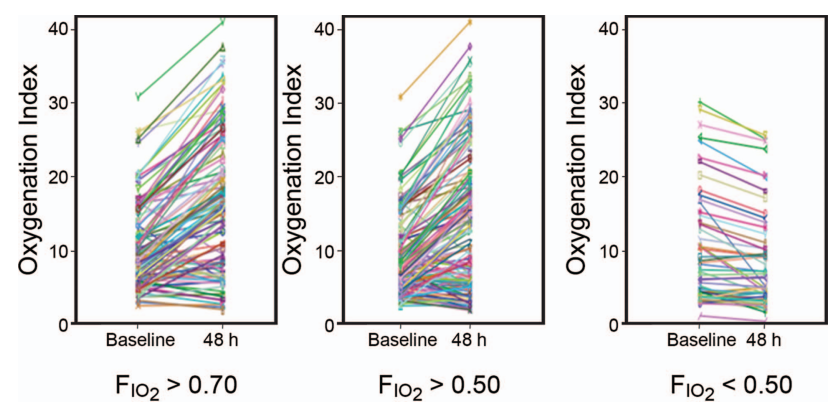

Fig. 7. Change in oxygenation index from initiation of mechanical ventilation (baseline) to $48 \mathrm{~h}$ after intubation, versus $\mathrm{F}_{\mathrm{IO}_{2}}$. From Reference 37.

ciation with more days on mechanical ventilation, longer ICU stay, and longer hospital stay. However, there was no impact on mortality. As with the ANZICS trial ${ }^{88}$, these findings could be attributed to the severity of illness. However, the exposure of the lung to excessive oxygen in the absence of need is a plausible argument for causation. But the argument here is mortality, and the burden of proof has not been met.

\section{The Conservative Oxygen Therapy Trials}

Suzuki et al ${ }^{89,91}$ evaluated the use of conservative oxygen therapy in 2 before and after trials. A definition of conservative oxygen therapy is in order before further discussion. According to Eastwood et al, ${ }^{98}$ conservative oxygen therapy targets an $\mathrm{F}_{\mathrm{IO}_{2}}$ of $90-92 \%$ at the lowest possible $\mathrm{F}_{\mathrm{IO}_{2}}$. Although PEEP is an integral part of oxygenation management in the mechanically ventilated patient, PEEP is not involved in this definition.

In their first trial, 105 subjects were studied, 51 under standard care and 54 following the switch to conservative oxygen therapy. ${ }^{89}$ During standard care, the mean $\mathrm{S}_{\mathrm{pO}_{2}}$ was $98 \%$, whereas during conservative oxygen therapy, the mean $\mathrm{S}_{\mathrm{pO}_{2}}$ was $95 \%$. The authors concluded that conservative oxygen therapy was feasible and free of adverse clinical or biochemical outcomes. This study did not attempt to ascertain mortality differences. In a secondary analysis of this same group of subjects, they determined the mean atelectasis score and time to first spontaneous 
breathing trial between groups. ${ }^{91}$ The atelectasis score was lower in the conservative oxygen therapy group, and the time to the first spontaneous breathing trial was shortened. So in a stretch of interpretation, you could say that conservative oxygen therapy may facilitate weaning by preventing progressive lung collapse. But in the end, this small cohort does not allow a mortality discussion.

Panwar et $\mathrm{al}^{92}$ evaluated the use of conservative oxygen therapy in 103 subjects in 4 Australian ICUs. $\mathrm{S}_{\mathrm{pO}_{2}}$ targets of $88-92 \%$ versus $>96 \%$ were compared across the duration of ventilatory support. The conservative oxygen therapy group achieved the desired $\mathrm{S}_{\mathrm{pO}_{2}}$ without any increase in the percentage of time with an $\mathrm{S}_{\mathrm{pO}_{2}}<88 \%$. Mortality was not altered in this trial. The authors concluded that conservative oxygen therapy was safe and feasible.

The most recent trial by Dutch investigators used a stepwise implementation of conservative oxygen therapy across a 3-y time frame. ${ }^{93}$ In the first step, the $\mathrm{S}_{\mathrm{pO}_{2}}$ target was $92-95 \%$, whereas the second step utilized a decision assist system to guide protocol adherence. The primary end point of the trial was achieving the oxygenation targets. Despite the lower $\mathrm{S}_{\mathrm{pO}_{2}}$ targets, there was no difference in the duration of hypoxic episodes. Ventilator-free days were greater in the 2 conservative oxygen therapy periods with an mean increase of $0.5 \mathrm{~d}$. Adjusted ICU and hospital mortality remained unchanged.

\section{The Con Summary}

These 6 trials do provide support that a conservative oxygen therapy approach is safe (no increase in hypoxemic events) and is a feasible strategy. In a few cases, excessive $\mathrm{F}_{\mathrm{IO}_{2}}$ has been associated with absorption atelectasis and worsening gas exchange. ${ }^{38,90,91}$ However, this typically occurs when $\mathrm{F}_{\mathrm{IO}_{2}}=1.0$, not because of need but as part of the study design. In more recent trials, there appears to be a signal related to the duration of ventilation. ${ }^{22,93}$ However, the question at hand, regarding mortality, remains, at best, unresolved. Even both recent meta-analyses concur that there is no definitive impact on mortality. ${ }^{94,95}$

\section{Excessive $\mathrm{F}_{\mathrm{IO}_{2}}$ in Other Conditions}

Although this debate is restricted to patients requiring mechanical ventilation for lung injury, there are a number of other disease states that may be worsened by hyperoxia. Common among these maladies are insults where ischemia/reperfusion plays an important role in pathogenesis of the disease. Ischemia followed by hyperoxemia creates a perfect milieu for potentiating injury via ROS production. These are considered briefly here.

\section{Myocardial Infarction/Cardiac Arrest}

Despite the fact that oxygen is widely prescribed following cardiac arrest and myocardial infarction, the negative physiologic effects of hyperoxia have been known for quite some time. ${ }^{99-101}$ Kilgannon et $\mathrm{al}^{63}$ have demonstrated that hyperoxia played a greater role in mortality than did hypoxia following cardiac arrest. A number of other investigations and meta-analyse ${ }^{102-107}$ on this subject have been published following the work of Kilgannon. Had this debate been about hyperoxia following cardiac arrest, the evidence falls heavily on the side of conservative oxygen therapy and prevention of hyperoxic conditions.

\section{Traumatic Brain Injury}

Traumatic brain injury represents another case where hyperoxia may be as dangerous as hypoxia. A number of animal studies and clinical investigations have shown the negative outcomes seen with both extremes of oxygenation. Oxygen has an important impact on cerebral perfusion and vasomotor tone in addition to its importance in meeting cerebral metabolic demands. Although the data are not as compelling as for cardiac arrest, hyperoxemia, in the face of normal intracranial pressure and brain tissue oxygen, appears to have negative consequences. ${ }^{108-111}$

\section{Stroke}

Ischemic brain injury following stroke also appears to be negatively influenced by hyperoxemia. These data often include subjects who are not mechanically ventilated, but the risk of worsening ischemia/reperfusion injury in stoke is compelling. ${ }^{64,112,113}$ A meta-analysis by Rincon and co-workers ${ }^{64}$ demonstrated a direct negative effect of hyperoxia on outcomes in mechanically ventilated subjects following stroke. In fact, the authors concluded: "In ventilated stroke patients admitted to the ICU, arterial hyperoxia was independently associated with in-hospital death as compared with either normoxia or hypoxia. These data underscore the need for studies of controlled reoxygenation in ventilated critically ill stroke populations. In the absence of results from clinical trials, unnecessary oxygen delivery should be avoided in ventilated stroke patients."

\section{Conclusions}

Oxygen has long been known to be toxic to the lungs, and an $\mathrm{F}_{\mathrm{IO}_{2}}$ of 1.0 is associated with adsorption atelectasis, alveolar collapse, and hypoxemia. Hyperoxic injury in other organ systems has become a new area of investigation wherein hyperoxemia can result in negative outcomes. Conservative oxygen therapy to target normoxemia can easily be defended without a large body of evidence regarding impact 
on mortality. Outside of carbon monoxide poisoning, decompression sickness, and gas embolism, an $\mathrm{F}_{\mathrm{IO}_{2}}$ of 1.0 has no benefits. Future conservative oxygen therapy trials may be facilitated by closed-loop control of $\mathrm{F}_{\mathrm{IO}_{2}}$, overcoming the problems with human control of a variable $\mathrm{S}_{\mathrm{pO}_{2}}$.

\section{REFERENCES}

1. Kallet RH, Matthay MA. Hyperoxic acute lung injury. Respir Care 2013;58(1):123-141.

2. Hubmayr RD. Does oxygen tune cellular mechanotransduction? Am J Physiol Lung Cell Mol Physiol 2012;302(12):L1233-L1234.

3. Fisher AB, Beers MF. Hyperoxia and acute lung injury. Am J Physiol Lung Cell Mol Physiol 2008;295(6):L1066.

4. Gerschman D, Gilbert DL, Nye SW, Dwyer P, Fenn WO. $\mathrm{O}_{2}$ poisoning and $\mathrm{X}$ irradiation: a mechanism in common. Science 1954; 119(3097):623-626.

5. Pratt PC. Pulmonary capillary proliferation induced by $\mathrm{O}_{2}$ ventilation. Am J Pathol 1958;34(6):1033-1049.

6. Ashbaugh DG, Bigelow DB, Petty TL, Levine BE. Acute respiratory distress in adults. Lancet 1967;2(7511):319-323.

7. Blaisdell FW, Stallone RJ. The mechanism of pulmonary damage following traumatic shock. Surg Gynecol Obstet 1970;130(1):15-22.

8. Powers SR Jr, Burdge R, Leather R, Monaco V, Newell J, Sardar $\mathrm{S}$, Smith EJ. Studies of pulmonary insufficiency in non-thoracic trauma J Trauma 12(1):1-14, 1972.

9. Pontoppidan H, Geffin B, Lowenstein E. Acute respiratory failure in the adult (first of three parts). N Engl J Med 1972;287(14):690-698.

10. Linton RC, Walker FW, Spoerel WE. Respirator care in a general hospital: a five-year survey. Can Anaesth Soc J 1965;12(5):451-457.

11. Fairley HB, Britt BA. The adequacy of the air-mix control in ventilators operated from an $\mathrm{O}_{2}$ source. Can Med Assoc J 1964;90(12): 1394-1396.

12. Pontoppidan H. Berry PR. Regulation of the inspired $\mathrm{O}_{2}$ concentration during artificial ventilation. JAMA 1967;201(1):89-92.

13. Webb HH, Tierney DF. Experimental pulmonary edema due to intermittent positive-pressure ventilation with high inflation pressures: protection by positive end-expiratory pressure. Am Rev Respir Dis 1974;110(5):556-565.

14. Dreyfuss D, Basset G, Soler P, Saumon G. Intermittent positivepressure hyperventilation with high inflation pressures produces pulmonary vascular injury in rats. Am Rev Respir Dis 1985;132(4): 880-884.

15. Dreyfuss D, Soler P, Basset G. High inflation pressure pulmonary edema. Respective effects of high airway pressure, high tidal volume and positive end-expiratory pressure. Am Rev Respir Dis 1988; 137(5):1159-1164.

16. Buczynski BW, Maduekwe ET, O'Reilly MA. The role of hyperoxia in the pathogenesis of experiemental BPD. Semin Perinatol 2013;37(2):69-78

17. Berner RA, Vandenbrooks JM, Ward PD. Evolution, Oxygen and evolution Science 2007;316(5824):557-558.

18. Falkowski PG, Katz ME, Milligan AJ, Fennel K, Cramer BS, Aubry MP, et al. The rise of oxygen over the past 205 million years and the evolution of large placental mammals. Science 2005; 309(5744):2202-2204.

19. Kielan-Jaworowska Z, Cifelli RL, Luo ZX. Mammals from the age of dinosaurs: origins, evolution and structure. New York: Columbia University Press; 2004.

20. Flück M, Webster KA, Graham J, Giomi F, Gerlach F, Schmitz A. Coping with cyclic oxygen availability: evolutionary aspects. Integr Comp Biol 2007;47(4):524-531.
21. Kuipers MT, van der Poll T, Schultz MJ, Wieland CW. Bench-tobedside review: damage-associated molecular patterns in the onset of ventilator-induced lung injury. Crit Care 2011;15(6):235.

22. Schreck R, Albermann K, Baeuerle PA. Nuclear factor kappa B: an oxidative stress-response transcription factor of eukaryotic cells (a review). Free Radic Res Commun 1992;17(4):221-237.

23. Chiang CH, Pai HI, Liu SL. Ventilator-induced lung injury (VILI) promotes ischemia/reperfusion lung injury (I/R) and NF-kB antibody attenuates both injuries. Resuscitation 2008;79(1):147-154.

24. Liu YY, Liao SK, Huang CC, Tsai YH, Quinn DA, Li LF. Role of nuclear factor-kB in augmented lung injury because of interactions between hyperoxia and high stretch ventilation. Transl Res 2009; 154(5):228-240.

25. Nieuwenhuizen L, de Groot PG, Grutters JC, Biesma DH. A review of pulmonary coagulopathy in acute lung injury, acute respiratory distress syndrome and pneumonia. Eur J Haematol 2009;82(6):413-425.

26. Li LF, Liao SK, Ko YS, Lee CH, Quinn DA. Hyperoxia increases ventilator-induced lung injury via mitogen-activated protein kinases: a prospective controlled animal experiment. Crit Care 2007;11(1):R25.

27. Quinn DA, Moufarrej RK, Volokhov A, Hales CA. Interactions of lung stretch, hyperoxia, and MIP-2 production in ventilator-induced lung injury. J Appl Physiol 2002;93(2):517-525.

28. Bailey TC, Martin EL, Zhao L, Veldhuizen RAW. High oxygen concentration predisposes mouse lungs to the deleterious effects of high stretch ventilation. J Appl Physiol 2003;94(3):975-982.

29. Sinclair SE, Altemeier WA, Matute-Bello G, Chi EY. Augmented lung injury due to interaction between hyerpoxia and mechanical ventilation. Crit Care Med 2004;32(12):2496-2501.

30. Roan E, Wilhelm K, Bada A, Makena PS, Gorantla VK, Sinclair SE, Waters CM. Hyperoxia alters the mechanical properties of alveolar epithelial cells. Am J Physiol Lung Cell Mol Physiol 2012; 302(12):L1235-L1241.

31. Ehlert CA, Truog WE, Thibeault DW, Garg U, Norberg M, Rezaiekhaligh $\mathrm{M}$, et al. Hyperoxia and tidal volume: independent and combined effects on neonatal pulmonary inflammation. Biol Neonate 2006;90(2):89-97.

32. Davis JM, Penney DP, Notter RH, Metlay L, Dickerson B, Shapiro DL. Lung injury in the neonatal piglet caused by hyperoxia and mechanical ventilation. J Appl Physiol 1989;67(3):1007-1012.

33. Makena PS, Luellen CL, Balazs L, Ghosh MC, Parthasarathi K, Waters CM, Sinclair SE. Preexposure to hyperoxia causes increased lung injury and epithelial apoptosis in mice ventilated with high tidal volumes. Am J Physiol Lung Cell Mol Physiol 2010;299(5): L711-L719.

34. Makena PS, Gorantla VK, Ghosh MC, Bezawada L, Balazs L, Luellen C, et al. Lung injury caused by high tidal volume mechanical ventilation and hyperoxia is dependent on oxidant-mediated c-Jun $\mathrm{NH}_{2}$-terminal kinase activation. J Appl Physiol 2011;111(5): 1467-1476.

35. Andrade PV, dos Santos JM, Silva HCA, Wilbert DD, Cavassani SS, Oliveira-Júnior IS. Influence of hyperoxia and mechanical ventilation in lung inflammation and diaphragm function in aged versus adult rats. Inflammation 2014;37(2):486-494.

36. Olivant Fisher A, Husain K, Wolfson MR, Hubert TL, Rodriguez E, Shaffer TH, Theroux MC. Hyperoxia during one lung ventilation: inflammatory and oxidative responses. Pediatr Pulmonol 2012; 47(10):979-986.

37. Lopez-Rodriguez E, Pérez-Gil J. Structure-function relationships in pulmonary surfactant membranes: from biophysics to therapy. Biochim Biophys Acta 2014;1838(6):1568-1585.

38. Rachmale S, Li G, Wilson G, Malinchoc M, Gajic O. Practice of excessive $\mathrm{F}_{\mathrm{IO}_{2}}$ and effect on pulmonary outcomes in mechanically ventilated patients with acute lung injury. Respir Care 2012;57(11): 1887-1893. 
39. Ames BN, Shigenaga MK, Hagen TM. Oxidants, antioxidants, and the degenerative diseases of aging. Proc Natl Acad Sci USA 1993; 90(17):7915-7922.

40. Gattinoni L, Protti A, Caironi P, Carlesso E. Ventilator-induced lung injury: The anatomical and physiological framework. Crit Care Med 2010;38(10):S539-S548.

41. Gattinoni L, Pesenti A. The concept of baby lung. Intensive Care Med 2005;31(6):776-784.

42. Terragni PP, Rosboch G, Tealdi A, Corno E, Menaldo E, Davini O, et al. Tidal hyperinflation during low tidal volume ventilation in acute respiratory distress syndrome. Am J Respir Crit Care Med 2007;175(2):160-166.

43. Bellani G, Messa C, Guerra L, Spagnolli E, Foti G, Patroniti N, et al. Lungs of patients with acute respiratory distress syndrome show diffuse inflammation in normally aerated regions: A $\left[{ }^{18} \mathrm{~F}\right]$-fluoro-2-deoxy-D-glucose PET/CT study. Crit Care Med 2009;37(7):2216-2222.

44. Petty TL, Stanford RE, Neff TA. Continuous oxygen therapy and chronic airway obstruction: observations on possible oxygen toxicity and survival. Ann Intern Med 1971;75(3):361-367.

45. Kirkham PA, Barnes PJ. Oxidative stress in COPD patients. Chest 2013;144(1):266-273.

46. Foschino Barbaro MP, Serviddio G, Resta O, Rollo T, Tamborra R, Elisiana Carpagnano G, et al. Oxygen therapy at low flow causes oxidative stress and chronic obstructive pulmonary disease: prevention by N-acetylcysteine. Free Radic Res 2005;39(10):1111-1118.

47. Ciencewicki J, Trivedi S, Kleeberger SR. Oxidants in the pathogenesis of lung diseases. J Allergy Clin Immunol 2008;122(3):456-468.

48. Tao F, Gonzalez-Flecha B, Kobzik L. Reactive oxygen species in pulmonary inflammation by ambient particulates. Free Radic Biol Med 2003;35(4):327-340.

49. Risom L, Møller P, Loft S. Oxidative stress-induced DNA damage by particulate air pollution. Mutat Res 2005;592(1):119-137.

50. Clark JM, Lambertsen CJ. Pulmonary $\mathrm{O}_{2}$ toxicity: a review. Pharmacol Rev 1971;23(2):37-133.

51. Finch CA, Lenfant C. Oxygen transport in man. N Engl J Med 1972;286(8):407-415.

52. Sjöberg F, Singer M. The medical use of oxygen: a time for critical reappraisal. J Intern Med 2013;274(6):505-528.

53. Eastwood GM, Young PJ, Bellomo R. The impact of oxygen and carbon dioxide management on outcome after cardiac arrest. Curr Opin Crit Care 2014;20(3):266-272.

54. Rousseau A, Bak Z, Janerot-Sjöberg B, Sjöberg F. Acute hyperoxaemia-induced effects on regional blood flow, oxygen consumption and central circulation in man. Acta Physiol Scand 2005;183(3):231-240.

55. Beynon C, Kiening KL, Orakcioglu B, Unterberg AW, Sakowitz OW. Brain tissue oxygen monitoring and hyperoxic treatment in patients with traumatic brain injury. J Neurotrauma 2012;29(12):2109-2123.

56. Meyhoff CS, Staehr AK, Rasmussen LS. Rational use of oxygen in medical disease and anesthesia. Curr Opin Anaesthesiol 2012;25(3): 363-370.

57. Sandroni C, D'Arrigo S. Management of oxygen and carbon dioxide pressure after cardiac arrest. Minerva Anestesiol 2014;80(10): 1105-1114.

58. Morita K. Surgical reoxygenation injury of the myocardium in cyanotic patients: clinical relevance and therapeutic strategies by normoxic management during cardiopulmonary bypass. Gen Thorac Cardiovasc Surg 2012;60(9):549-556.

59. Hlatky R, Valadka AB, Gopinath SP, Robertson CS. Brain tissue oxygen tension response to induced hyperoxia reduced in hypoperfused brain. J Neurosurg 2008;108(1):53-58

60. Hess ML, Manson NH. Molecular oxygen: friend and foe: the role of the oxygen free radical system in the calcium paradox, the oxygen paradox and inschemia/reperfusion injury. J Mol Cell Cardiol 1984;16(11):969-985.
61. Nastos C, Kalimeris K, Papoutsidakis N, Tasoulis MK, Lykoudis $\mathrm{PM}$, Theodoraki K, et al. Global consequences of liver ischemia/ reperfusion injury. Oxid Med Cell Longev 2014;906965.

62. Pilcher J, Weatherall M, Shirtcliffe P, Bellomo R, Young P, Beasley R. The effect of hyperoxia following cardiac arrest: a systematic review and meta-analysis of animal trials. Resuscitation 2012; 83(4):417-422.

63. Kilgannon JH, Jones AE, Shapiro NI, Angelos MG, Milcarek B, Hunter $\mathrm{K}$, et al. Association between arterial hyperoxia following resuscitation from cardiac arrest and in-hospital mortality. JAMA 2010;303(21):2165-2171

64. Rincon F, Kang J, Maltenfort M, Vibbert M, Urtecho J, Athar MK, et al. Association between hyperoxia and mortality after stroke: a multicenter cohort study. Crit Care Med 2014;42(2):387-396.

65. Rincon F, Kang J, Vibbert M, Urtecho J, Athar MK, Jallo J. Significance of arterial hyperoxia and relationship with case fatality in traumatic brain injury: a multicentre cohort study. J Neurol Neurosurg Psychiatry 2014;85(7):799-805.

66. Zangl Q, Martignoni A, Jackson SH, Ohta A, Klaunberg B, Kaufmann I, et al. Postoperative hyperoxia (60\%) worsens hepatic injury in mice. Anesthesiology 2014;121(6):1217-1225.

67. Wang Y, Yuan L, Liu P, Zhao M. Delayed hyperoxic ventilation attenuates oxygen-induced free radical accumulation during early reperfusion after global brain ischemia. Neuroreport 2015;26(3): 131-138.

68. Cameron L, Pilcher J, Weatherall M, Beasley R, Perrin K. The risk of serious adverse outcomes associated with hypoxaemia and hyperoxaemia in acute exacerbations of COPD. Postgrad Med J 2012; 88(1046):684-689.

69. Austin MA, Wills KE, Blizzard L, Walters EH, Wood-Baker R. Effect of high flow oxygen on mortality in chronic obstructive pulmonary disease patients in prehospital setting: randomized controlled trial. BMJ 2010;341:c5462.

70. Soler-Cataluna JJ, Martínez-García MA, Román Sanchez P, Salcedo E, Navarro M, Ochando R. Severe acute exacerbations and mortality in patiens with chronic obstructive pulmonary disease. Thorax 2005;60(11):925-931.

71. de Jonge E, Peelen L, Keijzers PJ, Joore H, de Lange D, van der Voort PHJ, et al. Association between administered oxygen, arterial partial oxygen pressure and mortality in mechanically ventilated intensive care unit patients. Crit Care 2008;12(6):R156.

72. Abdelsalam M, Cheifetz IM. Goal-directed therapy for severely hypoxic patients with acute respiratory distress syndrome: permissive hypoxemia. Respir Care 2010;55(11):1483-1490.

73. Lund T, Koller ME, Kofstad J. Severe hypoxemia without evidence of tissue hypoxia in adult respiratory distress syndrome. Crit Care Med 1984;12(1):75-76.

74. Boissier F, Katsahian S, Razazi K, Thille AW, Roche-Campo F, Leon R, et al. Prevalance and prognosis of cor pulmonale during protective ventilation for acute respiratory distress syndrome. Intensive Care Med 2013;39(10):1725-1733.

75. Bull TM, Clark B, McFann K, Moss M, National Institutes of Health/National Heart, Lung, and Blood Institute ARDS Network. Pulmonary vascular dysfunction is associated with poor outcomes in patients with acute lung injury. Am J Respir Crit Care Med 2010;182(9):1123-1128.

76. SUPPORT Study Group of the Eunice Kennedy Shriver NICHD Neonatal Research Network, Carlo WA, Finer NN, Walsh MC, Rich W, Gantz MG, et al. Target ranges of oxygen saturation in extremely preterm infants. N Engl J Med 2010;362(21):1959-1969.

77. BOOST II United Kingdom Collaborative Group, BOOST II Australia Collaborative Group, BOOST II New Zealand Collaborative Group, Stenson BJ, Tarnow-Mordi WO, Darlow BA, et al. Oxygen 
saturation and outcomes in preterm infants. N Engl J Med 2013; 368(22):2094-2104.

78. Martin DS, Grocott MPW. Oxygen therapy in critical illness: precise control of arterial oxygenation and permissive hypoxemia. Crit Care Med 2013;41(2):423-432.

79. Malley WJ. Clinical blood gases: assessment and intervention, 2nd edition. St Louis: Elsevier/Saunders; 2005:170.

80. Nitzan M, Romem A, Koppel R. Pulse oximetry: fundamentals and technology update. Med Devices (Aukl) 2014;7:231-239. doi: 10.2147/MDER.S47319.

81. West JB. Respiration physiology: the essentials, 9th edition. Philadelphia: Wolters Kluther/Lippincott Williams \& Wilkins; 2012; 80.

82. The Acute Respiratory Distress Syndrome Network. A trial of traditional tidal volume versus lower tidal volume ventilation in acute lung injury and acute respiratory distress syndrome. N Engl J Med 2000;342(18):1301-1308.

83. Leverve XM. To cope with oxygen: a long and still tumultuous story for life. Crit Care Med 2008;36(2):637-638.

84. Hafner S, Beloncle F, Koch A, Radermacher P, Asfar P. Hyperoxia in intensive care, emergency and peri-operative medicine: Dr. Jekyll or Mr. Hyde? a 2015 update. Ann Intensive Care 2015(1);5:42.

85. Helmerhorst HJF, Schultz MJ, van der Voort PHJ, de Jonge E, van Westerloo DJ. Bench to bedside review: the effects of hyperoxia during critical illness. Crit Care 2015;19:284.

86. Ray PD, Huang BW, Tsuji Y. Reactive oxygen species (ROS) homeostasis and redox regulation in cellular signaling. Cell Signal 2012;24(5):981-990.

87. Severinghaus JW, Astrup PB. History of blood gas analysis. IV. Leland Clark's oxygen electrode. J Clin Monit 1986;2(2):125-139.

88. Eastwood G, Bellomo R, Bailey M, Taori G, Pilcher D, Young P, Beasley R. Arterial oxygen tension and mortality in mechanically ventilated patients. Intensive Care Med 2012;38(1):91-98.

89. Suzuki S, Eastwood GM, Glassford NJ, Peck L, Young H, GarciaAlvarez M, et al. Conservative oxygen therapy in mechanically ventilated patients: a pilot before-and-after trial. Crit Care Med 2014;42(6): 1414-1422.

90. Aboab J, Jonson B, Kouatchet A, Taille S, Niklason L, Brochard L. Effect of inspired oxygen fraction on alveolar derecruitment in acute respiratory distress syndrome. Intensive Care Med 2006; 32(12):1979-1986.

91. Suzuki S, Eastwood GM, Goodwin MD, Noë GD, Smith PE, Glassford $\mathrm{N}$, et al. Atelectasis and mechanical ventilation mode during conservative oxygen therapy: a before-and-after study. J Crit Care 2015;30(6):1232-1237.

92. Panwar R, Hardie M, Bellomo R, Barrot L, Eastwood GM, Young $\mathrm{PJ}$, et al. Conservative versus liberal oxygenation targets for mechanically ventilated patients. a pilot multicenter randomized controlled trial. Am J Respir Crit Care Med 2016;193(1):43-51.

93. Helmerhorst HJ, Schultz MJ, van der Voort PH, Bosman RJ, Juffermans NP, de Wilde RB, et al. Effectiveness and clinical outcomes of a two-step implementation of conservative oxygenation targets in critically ill patients: a before and after trial. Crit Care Med 2016;44(3):554-563.

94. Helmerhorst HJ, Roos-Blom MJ, van Westerloo DJ, de Jonge E. Association between arterial hyperoxia and outcome in subsets of critical illness: a systematic review, meta-analysis, and meta-regression of cohort studies. Crit Care Med 2015;43(7):1508-1519.

95. Damiani E, Adrario E, Girardis M, Romano R, Pelaia P, Singer M, Donati A. Arterial hyperoxia and mortality in critically ill patients: a systematic review and meta-analysis. Crit Care 2014;18(6):711.

96. de Graaff AE, Dongelmans DA, Binnekade JM, de Jonge E. Clinicians' response to hyperoxia in ventilated patients in a Dutch ICU depends on the level of $\mathrm{F}_{\mathrm{IO}_{2}}$. Intensive Care Med 2011;37(1):46-51.
97. Lenfant C. Effect of high $\mathrm{F}_{\mathrm{IO}_{2}}$ on measurement of ventilation/perfusion in man at sea level. Ann N Y Acad Sci 1965;121:797-808.

98. Eastwood GM, Peck L, Young H, Suzuki S, Garcia M, Bellomo R. Intensive care clinicians' opinion of conservative oxygen therapy $\left(\mathrm{S}_{\mathrm{pO}_{2}} 90-92 \%\right)$ for mechanically ventilated patients. Aust Crit Care 2014;27(3):120-125.

99. Ganz W, Donoso R, Marcus H, Swan HJ. Coronary hemodynamics and myocardial oxygen metabolism during oxygen breathing in patients with and without coronary artery disease. Circulation 1972; 45(4):763-768.

100. Mak S, Azevedo ER, Liu PP, Newton GE. Effect of hyperoxia on left ventricular function and filling pressures in patients with and without congestive heart failure. Chest 2001;120(2):467-473.

101. McNulty PH, King N, Scott S, Hartman G, McCann J, Kozak M, et al. Effects of supplemental oxygen administration on coronary blood flow in patients undergoing cardiac catheterization. Am J Physiol Heart Circ Physiol 2005;288(3):H1057-H1062.

102. Eastwood GM, Tanaka A, Espinoza ED, Peck L, Young H, Mårtensson J, et al. Conservative oxygen therapy in mechanically ventilated patients following cardiac arrest: a retrospective nested cohort study. Resuscitation 2016;101:108-114.

103. Zhao S, Qian J, Wang J, Gong P, Yang Z, Cahoon J, et al. Effects of oxygen concentrations on postresuscitation myocardial oxidative stress and myocardial function in a rat model of cardiopulmonary resuscitation. Crit Care Med 2015;43(12):e560-e566.

104. Helmerhorst HJ, Roos-Blom MJ, van Westerloo DJ, Abu-Hanna A, de Keizer NF, de Jonge E. Associations of arterial carbon dioxide and arterial oxygen concentrations with hospital mortality after resuscitation from cardiac arrest. Crit Care 2015;19:348.

105. Elmer J, Scutella M, Pullalarevu R, Wang B, Vaghasia N, Trzeciak $\mathrm{S}$, et al. The association between hyperoxia and patient outcomes after cardiac arrest: analysis of a high-resolution database. Intensive Care Med 2015;41(1):49-57.

106. Wang $\mathrm{CH}$, Chang WT, Huang $\mathrm{CH}$, Tsai MS, Yu PH, Wang AY, et al. The effect of hyperoxia on survival following adult cardiac arrest: a systematic review and meta-analysis of observational studies. Resuscitation 2014;85(9):1142-1148.

107. Bellomo R, Bailey M, Eastwood GM, Nichol A, Pilcher D, Hart GK, et al. Arterial hyperoxia and in-hospital mortality after resuscitation from cardiac arrest. Crit Care 2011;15(2):R90.

108. Vilalta A, Sahuquillo J, Merino MA, Poca MA, Garnacho A, Martínez-Valverde T, Dronavalli M. Normobaric hyperoxia in traumatic brain injury: does brain metabolic state influence the response to hyperoxic challenge? J Neurotrauma 2011;28(7):1139-1148.

109. Rangel-Castilla L, Lara LR, Gopinath S, Swank PR, Valadka A, Robertson C. Cerebral hemodynamic effects of acute hyperoxia and hyperventilation after severe traumatic brain injury. J Neurotrauma 2010;27(10): 1853-1863.

110. Rockswold SB, Rockswold GL, Zaun DA, Zhang X, Cerra CE, Bergman TA, Liu J. A prospective, randomized clinical trial to compare the effect of hyperbaric to normobaric hyperoxia on cerebral metabolism, intracranial pressure, and oxygen toxicity in severe traumatic brain injury. J Neurosurg 2010;112(5):1080-1094.

111. Davis DP, Meade W, Sise MJ, Kennedy F, Simon F, Tominaga G, et al. Both hypoxemia and extreme hyperoxemia may be detrimental in patients with severe traumatic brain injury. J Neurotrauma 2009;26(12):2217-2223.

112. Tiwari YV, Jiang Z, Sun Y, Du F, Rodriguez P, Shen Q, Duong TQ. Effects of stroke severity and treatment duration in normobaric hyperoxia treatment of ischemic stroke. Brain Res 2016;1635:121-129.

113. Wu O, Lu J, Mandeville JB, Murata Y, Egi Y, Dai G, et al. Dynamic functional cerebral blood volume responses to normobaric hyperoxia in acute ischemic stroke. J Cereb Blood Flow Metab 2012;32(9):1800-1809. 


\section{Discussion}

Marini: I found both presentations stimulating. In Rich's [Kallet] talk, the multiplier of metabolism and $\mathrm{F}_{\mathrm{IO}_{2}}$ for injury resonated with what we found in the lab over the years with other VILI co-factors. I've said this so much I guess it's old hat to all here, but you can take exactly the same injurious pattern of inflation and match it with different vascular patterns, or temperatures - temperatures only, not metabolism-and get totally different expressions of VILI. I think it's a very real and important point you brought out. The second thing is you didn't mention Grocott and Martin's work ${ }^{1}$ with high altitude acclimatization, the Everest project, etc. I find that stuff interesting because as an out-patient clinician for much of my life, I would have patients walk into my clinic with $\mathrm{P}_{\mathrm{O}_{2}}$ levels that were amazingly low. One guy I remember from Seattle had a blood gas that I drew myself in the office of $20 \mathrm{~mm} \mathrm{Hg}$. I yelled at the lab for screwing it up, drew a second one, and it came back 19! I drew 19, 20, and 21 with double analyses on everything. And he was just feeling a little under the weather. The point is he was adapted. We know very little about adaptation and its potential. If we had reliable markers of intolerance, we might be able to reduce $\mathrm{F}_{\mathrm{IO}_{2}}$ quite a bit.

Branson: This idea of permissive hypercapnia or hypoxemia basically attempts to acclimatize patients in the ICU. We've got to have that central area we're looking at where we like the saturations to be $>85 \%$ or whatever your preference. What if over a couple of days we just went from accepting $89 \%$ to accepting $87 \%$, to $85 \%$, and so on? Clearly we get worried when a patient is severely hypoxemic until they're on $20 \mathrm{~cm} \mathrm{H}_{2} \mathrm{O}$ of PEEP and their $\mathrm{F}_{\mathrm{IO}_{2}}$ is $100 \%$ and their $\mathrm{P}_{\mathrm{aO}_{2}}$ is 35 or $40 \mathrm{~mm} \mathrm{Hg}$ and everything seems fine. There probably is some acclimatization that can take place in critically ill patients. Obviously, that needs a lot more research on how to implement that strategy and what are the other factors in terms of sufficient cardiac output, sufficient hemoglobin in order to make that happen at the bedside.

MacIntyre: I did a Journal Conference $\operatorname{paper}^{2}$ on this several years ago, and it's fascinating, John. One of the most dramatic changes, and I don't understand it, is you take a fetus that's thriving with a $\mathrm{P}_{\mathrm{O}_{2}}$ in the $30 \mathrm{~s}$, and then at the moment of delivery, it rapidly converts to a creature that will die with a $\mathrm{P}_{\mathrm{O}_{2}}$ of 30 . Clearly, there are adaptive mechanisms that are capable of keeping this creature alive beautifully in utero that change quite dramatically when they're ex utero. Can we reverse that in an ICU setting? I obviously don't know the answer to that. Sherpas and others over many weeks or months clearly adapt and go climb up Mount Everest without $\mathrm{O}_{2}$. That puts their $\mathrm{P}_{\mathrm{O}_{2}}$ down in the 30s or even the 20 s. So, clearly there are hypoxia-adaptive mechanisms within our cells. How to tap into them and activate them and use them wisely is a huge question mark but could have great potential.

Berra: The final stop of oxygen is the mitochondria. The target is to keep the mitochondrial oxygenation with a few $\mathrm{mm} \mathrm{Hg}$ of mitochondrial $\mathrm{P}_{\mathrm{aO}_{2}}$. During hypoxemia in high altitude or extreme exercise, the cardiac output supplies the low oxygen content by increasing the oxygen delivery. Thus, it is very hard for me to understand studies that do not present cardiac output and hemodynamics of these patients. It is not only a matter of oxygenation levels in the blood, but it is relevant to study the delivery of oxygen and the hemodynamics

Kallet: I think one of the things to answer this question is not the sherpas who live up in the Himalayas and are adapted to that, but the yuppies who climb Mount Everest. People who aren't acclimated to hypoxemia. How long does it take a normal person who's climbing Mount Everest to acclimate to the hypoxic environment?

Mireles-Cabodevila: Weeks to months.

Kallet: Doesn't really apply to critical care medicine.

Mireles-Cabodevila: The part that bothers me about hypoxemia/hyperoxia is that in ARDS they also have inflammatory processes everywhere else. When you think about the areas of most concern regarding the degree of hypoxemia/hyperoxia is in the brain. The long-term outcomes of these patients after lung injury, in terms of performance, may be affected by a very tight behavior in that area. That remains to be studied.

Kallet: There have been a few papers published on the topic of post-traumatic stress disorder in ARDS. One study ${ }^{3}$ found that neurocognitive impairment at $1 \mathrm{y}$ was associated with prolonged periods of oxygen desaturation. There was another study, I think by ARDS Net, that found similar results between neurocognitive impairment at $1 \mathrm{y}$ and oxygenation. ${ }^{4}$ It's really a nettlesome problem.

Holets: There's a paper coming out that Dr Rachmale Pannu from Mayo Clinic presented in abstract form at SCCM (Society of Critical Care Medicine) on a therapist-driven protocol using an electronic alert system to avoid hyperoxemia in patients. Although the study was small and there was no change seen in mortality, there was a near significant trend toward decreased ventilator days and ICU stay in the intervention group.

Branson: I actually believe that hyperoxia is a real problem in the ICU 
Regulation of $\mathrm{O}_{2}$ Therapy in Critically Ill Patients

and we should do what we can to avoid it. Whether it's closed-loop control of $\mathrm{F}_{\mathrm{IO}_{2}}$ or RT-led protocols. Having people on $40 \% \mathrm{O}_{2}$ with a $\mathrm{P}_{\mathrm{O}_{2}}$ of 150 doesn't make any sense.

Mireles-Cabodevila: Except for your VAEs [ventilator-associated events].

\section{References}

1. Martin DS, Grocott MP. Oxygen therapy in critical illness: precise control of arterial oxygenation and permissive hypoxemia. Crit Care Med 2013;41(2):423-432.

2. MacIntyre NR. Supporting oxygenation in acute respiratory failure. Respir Care 2013; 58(1):142-150.

3. Hopkins RO, Weaver LK, Pope D, Orme JF, Bigler ED, Larson-Lohr V. Neuropsy- chological sequelae and impaired health status in survivors of severe acute respiratory distress syndrome. Am J Respir Crit Care Med 1999;160(1):50-56.

4. Mikkelsen ME, Christie JD, Lanken PN, Biester RC, Thompson BT, Bellamy SL, et al. The adult respiratory distress syndrome cognitive outcome study: long term neuropsychological function in survivors of acute lung injury. Am J Respir Crit Care Med 2012;185(12):1307-1315. 